\title{
Çevre Dostu Ambalajlı Ürün Özelliklerinin Tüketici Tutum ve Satın Alma Niyetine Etkisi (Effect of Eco-Friendly Packaged Product Properties on Consumer Attitudes and Purchase Intentions)
}

\section{Bülent ÖZSAÇMACI ${ }^{(D)}$ a Handan ÖZDEMİR ${ }^{(D)}$ b}

a Çankaya Üniversitesi, Çankaya Meslek Yüksekokulu, Dış Ticaret Programı, Ankara, Türkiye. bozsacmaci@cankaya.edu.tr

b Çankaya Üniversitesi, Halkla İlişkiler Bölümü, Çankaya, Türkiye. hozdemir@cankaya.edu.tr

\begin{tabular}{|c|c|}
\hline MAKALE BİLGİsí & ÖZET \\
\hline Anahtar Kelimeler: & Amaç - Bu çalışmanın amacı çevre dostu ambalajlı market ürünlerine ait fiyat, tasarım, algılanan \\
\hline $\begin{array}{l}\text { Çevre Dostu Ambalajlama } \\
\text { Satın Alma Niyeti }\end{array}$ & $\begin{array}{l}\text { kalite, çevresel tutum, beklenen fayda ve bilgi birikimi değişkenlerinin tüketicilerin tutumlarına, } \\
\text { farkındalıklarına ve satın alma niyetlerine etkisini ortaya koymaktır. }\end{array}$ \\
\hline $\begin{array}{l}\text { Çevresel Tutum, Çevresel } \\
\text { Farkındalık }\end{array}$ & $\begin{array}{l}\text { Yöntem - Bu çalışma nicel verilere dayalı genel tarama modelinde (betimsel) uygulamalı bir } \\
\text { arastırma örneği sunmaktadır. Calısma kapsamında kolayda örnekleme vöntemi benimsenmis ve }\end{array}$ \\
\hline Çevre Dostu Pazarlama & bu işlem için çevrimiçi anket uygulaması yürütülmüştür. 401 kişiden elde edilen anket verileri; SPSS \\
\hline Faaliyetleri & $\begin{array}{l}21.0 \text { istatistik programı kullanılarak tasnif ve analiz edilmiş, ANOVA, çoklu regresyon analizi ve T- } \\
\text { testi ile değerlendirilmiştir. }\end{array}$ \\
\hline $\begin{array}{l}\text { Gönderilme Tarihi } 6 \text { Temmuz } \\
2020 \\
\text { Revizyon Tarihi } 20 \text { Ağustos } \\
2020\end{array}$ & $\begin{array}{l}\text { Bulgular - Çevre dostu ambalajlı market ürünlerine ait fiyat, tasarım, algılanan kalite, çevresel } \\
\text { tutum, beklenen fayda ve bilgi birikimi değişkenlerinin; tüketicilerin çevre dostu ambalajlı ürünlere } \\
\text { yönelik tutumlarını, farkındalıklarını ve satın alma niyetlerini olumlu etkilediğini, buna karşın } \\
\text { demografik faktörlerin ise bu değişkenlerle anlamlı bir farklılık göstermediği anlaşılmıştır. }\end{array}$ \\
\hline $\begin{array}{l}\text { Makale Kategorisi: } \\
\text { Araştırma Makalesi }\end{array}$ & $\begin{array}{l}\text { Tartışma - Çevre dostu ürün uygulamaları konusunda yapılacak çalışmaların sayısının artması ile } \\
\text { çevre dostu ürünlere ve onların özelliklerine ilişkin bilinç ve tutumu olumlu yönde etkileyeceği } \\
\text { düşünülmektedir. Sektörde yer alan yöneticiler, mevcut çalışmadan elde edilen bulgular } \\
\text { doğrultusunda; tasarım anlamında çevre dostu özellikleri ön plana çıaracak, tüketici tutumunu ve } \\
\text { talebini çevre dostu ambalajlı ürünlere yöneltecek ve daha az malzeme ve kaynak kullanılmasıyla } \\
\text { çevre dostu üretim süreçlerinin benimseyecek uygulamalara yönelmesi sağlanabilir. }\end{array}$ \\
\hline
\end{tabular}

\begin{tabular}{l} 
ARTICLE INFO \\
\hline Keywords: \\
Eco-Friendly Packaging \\
Purchasing Intention \\
Environmental Attitude \\
Environmental Awareness \\
Eco-Friendly Marketing \\
Activities
\end{tabular}

Received 6 July 2020

Revised 20 August 2020

Accepted 15 September 2020

Article Classification:

Research Article

\section{ABSTRACT}

Purpose - The purpose of this study is to reveal the effects of the variables as; price, design, perceived quality, environmental attitude, expected benefit and knowledge of eco-friendly packaged market products on consumers' attitudes, awareness and purchasing intentions.

Design/methodology/approach - This study presents an applied research sample in the general survey design model (descriptive) based on quantitative data. Within the scope of the study, convenience sampling method was adopted, and online survey application was carried out for this process. Survey data obtained from 401 people; It was classified and analyzed using SPSS 21.0 statistical program, and ANOVA was evaluated by multiple regression analysis and T-test.

Findings - In terms of the variables included in the study, it was understood that it positively affected the attitudes, awareness, and purchase intentions of consumers towards environmentally friendly packaged products, whereas demographic factors did not differ significantly with these variables.

Discussion - The increasing number of studies on eco-friendly product practices will positively affect the awareness and attitude towards environmentally friendly products and their properties. The increasing number of studies on environmentally friendly product practices will positively affect the awareness and attitude towards environmentally friendly products and their properties. Practitioners in the field of marketing could contribute to this novel eco-friendly movement by highlighting eco-friendly features in terms of design, using sales promotion and publicity tools for directing consumer attitude and demand to eco-friendly packaged products, and enabling ecofriendly production processes for using less materials and resources for environmental purposes.

\section{Önerilen Atıf/ Suggested Citation}

Özsaçmacı, B., Özdemir, H. (2020). Çevre Dostu Ambalajlı Ürün Özelliklerinin Tüketici Tutum ve Satın Alma Niyetine Etkisi, İşletme Araştırmaları Dergisi, 12 (3), 2682-2701. 


\section{Giriş}

Günümüzde, alternatif olarak, "çevre dostu", "çevreye duyarlı" ya da "sürdürülebilir" olarak da bilinen (Kim vd., 2013) "yeşil" kavramı, doğal kaynakların yok edilmesine yönelik farkındalığın artmasıyla popülerlik kazanmaya başlamıştır. Çeşitli sektörlerdeki üretim anlayışının ve tüketim davranışının da yeşil pazarlama ve sürdürebilirlik gibi olgularla topluma yayılması, bu konudaki hassasiyetin önemini ayrıca ortaya koymaktadır.

Yakın tarihli araştırmalar (Scott ve Vigar-Ellis, 2014; Stolz vd., 2013) göstermektedir ki; bazı tüketiciler, ambalajlama seçeneklerinin oluşturacağı etkiyi de göz ününe alarak sürdürülebilir kalkınmaya, özellikle de çevre korumasına katkı sağlamak için motive olmuşlardır. Tüketicilerin gün içerisinde karşı karşıya kaldıkları ürün sayısı ve çeşidi sürekli olarak artmaktadır. Son dönemlerde tüketicilerin daha da bilinçli bir hal almasıyla sadece günlük tüketim ürünlerinin değil, aynı zamanda bu ürünleri üreten işletmelerin üretim süreçlerinin de göz önüne alınmaya başlamıştır. Tüketicinin hem kendisi hem de çevresi için; sağlıklı seçenekler ve etik iş uygulamaları konusunda bilgi arayışına daha fazla önem vermesi, endüstrileri de yeşil ve sürdürülebilir girişimler geliştirmeye zorlamaktadır. Yeşil tüketim konusunda yapılan araştırmalar, uygun fırsatların (çeşitlilik ve maliyet gibi) oluşması durumunda tüketicilerin yeşil ürün satın alma alışkanlıklarını kullanmak istediklerini öne sürmektedir (Kabadayı vd., 2015; Royne vd., 2011; Chen, 2010).

Geleneksel yaklaşımda üretim, tüketim, atık ve yeniden imalat süreçleri çevreye zarar verebilecek pek çok aşamadan oluşmaktadır. Bu süreç yalnızca atıkla sınırlı kalmamakta, hammadde, doğal kaynak, enerji ve çaba israfına da yol açabilmektedir (Fitzpatrick vd., 2012). Çevreye duyarlı üretim ve tüketim yapmanın çeşitli yolları olabilir ki bunlardan biri de yeşil ambalajlama, çevre dostu ambalajlama, sürdürülebilir ambalajlama olarak da bilinen çevreye duyarlı ya da çevre hassasiyetine sahip ambalajlama ile gerçekleşmektedir (Herbes vd., 2018).

Çevresel açıdan sürdürülebilir ya da "yeşil" satın alma kararları, çevre dostu ürünlerin benimsenmesiyle olumsuz çevresel etkileri azaltma şansı sunmaktadır (Leonidou vd., 2013). Hane halkı tüketiminde market harcamaları önemli bir paya sahiptir ve çevresel etkinin üçte birinden fazlası çoğunlukla ambalaj malzemelerinden kaynaklanmaktadır (Koenig-Lewis vd., 2014). Türkiye' de de değişen tüketim alışkanlıkları, nüfus artışı, yükselen hayat standardı, ambalajlı ürün satışındaki artış ile katı atık kompozisyonu da değişmektedir. Genel olarak bakıldığında, atılan atıkların ağırlıkça \%30'unu ve hacim olarak \%50'sini ambalaj atıkları oluşturmaktadır (Türkiye Çevre ve Şehircilik Bakanlığı, 2016).

Çevre dostu ambalajlamada gündemde yer alan yaklaşımlardan biri de imalatçılar tarafından biyokütleden (biomass) üretilen malzemeye dayanarak kullanılan biyolojik-tabanlı (biobased) uygulamalardır (Brockbaus vd., 2016). Ambalajlama malzemeleri; soya, mısır, pirinç ve manyok gibi mahsuller başta gelmek üzere, hali hazırda temin edilebilen çok çeşitli hammaddelerden üretilebilmektedir (Wang ve Wang, 2017). Bu sektörün dinamik yapısı ve çeşitliliği, geniş kapsamlı potansiyeli konusunda imalatçılar açısından seçenekleri arttırmaktadır. European Bioplastics, 2016 yılı raporuna göre biyoplastiklerin toplam küresel üretim kapasiteleri 2014 yılında 1,7 milyon tona ulaşmışır ve 2019 yılı sonunda da 8 milyon tonu aşması beklenmektedir. Bu malzemelerin en büyük uygulama bölümünü ise ambalajlar oluşturmaktadır (Herbes vd., 2018). İmalatçıların, çevre dostu ambalajı nasıl tanımladıklarını ve bu ambalajlar arasındaki farklılıkları tercihlerine nasıl yansıttıklarını anlamaları gerekmektedir. İmalatçılar tüketicileri taleplerini ne kadar iyi anlayabilirlerse, işletmelerini kar eden ve çevreyi korumayı destekleyen bir yapıya taşımaları o kadar kolay olacaktır. Akademik çevrelerce son yıllarda popülerleşmeye başlayan bu konuyla ilgili ülkemizde az sayıda çalışmaya rastlanmaktadır. Bu çalışma ile market ürünlerindeki çevre dostu ambalaj özelliklerini vurgulayan değişkenlerin tüketicilerin satın alma niyeti üzerindeki etkisinin incelenmesi amaçlanmaktadır. Bunun yanı sıra tüketicilerin çevre dostu ambalajlama konusundaki farkındalıkları da irdelenecektir. Bu kapsamda öncelikle literatür taraması ambalajlama, tüketici davranışları ve çevre dostu uygulamalar ekseninde ele alınacak, ardından kavramsal çerçeve ve metodoloji aktarıldıktan sonra analiz sonuçları ve öneriler kısımlarına yer verilecektir.

\section{Literatür Taraması}

Tüketicilerin bir ürüne ilişkin beklentileri; inanışlarından, deneyimlerinden ve bir ürünün ambalajının özellikleri gibi dışsal özelliklerinden kaynaklanır. Bu bağlamda, bir ürün ambalajının dış görünümü, tüketici 


\section{B. Özsaçmac1 - H. Özdemir 12/3 (2020) 2682-2701}

beklentilerinin oluşmasında ve satın alma isteğini gerçekleştirmesinde önemli bir role sahiptir (PiquerasFiszman ve Spence, 2015). Batı (2017), tasarım, ambalaj ve kullanılabilirlik gibi özelliklerin, tüketicileri markaya çekme konusunda çok önemli bir yere sahip olduğunu belirtmiş ve markaların atması gereken önemli adımlardan birinin de tasarımla kişilerde heyecan, güven, neşe, vb. olumlu duygular yaratmak olduğunu ifade etmiştir. Bu olumlu duygular sayesinde işletmeler markalarını yönetmekte, müşterilerini daha yakından tanımakta ve onlara özgü verimli pazarlama düzenlemelerini yapmaktadırlar.

Ambalajlamanın önemi ve bir iletişim aracı olarak kullanılması, markaların popülerliğini etkilemektedir (Sheth, 2011). Günümüzde farklı sektörlerden pek çok küresel marka ambalaj malzemelerini çevre dostu içerikli olanlarla değiştirmiştir. Bu "yeşil" girişimler, tüketicinin satın alma kararına ve belirli markaların seçimine yönelik tutum değişikliğine yansımıştır (Han vd., 2009). Rokka ve Uusitalo (2008), ürün ambalajının tüketici seçiminde önemli bir ürün özelliği olduğunu ve yeşil ambalajın tüketicinin tercihi üzerinde bir etkiye sahip olduğunu ifade etmiştir.

Sürdürülebilir Ambalajlama Koalisyonu, sürdürülebilir ambalajlamayı sekiz kritere göre tanımlamıştır. Sürdürülebilir ambalajlama; yaşam döngüsü boyunca bireyler ve topluluklar için faydalı, güvenli ve sağlıklı; performans ve maliyetler için pazar ölçütlerini karşılayan; üretilebilen, taşınır ve geri dönüştürülür yenilenebilir enerji kaynaklarını kullanan; geri dönüştürülmüş kaynak malzemenin kullanımını optimize eden; temiz üretim teknolojileri ve en iyi uygulamalar kullanılarak üretilmiş; yaşam döngüsü boyunca sağliklı malzemelerden yapılmış; malzeme ve enerjiyi optimize etmek için fiziksel olarak tasarlanmış ve biyolojik olarak ve / veya endüstriyel kapalı döngü sistemlerinde etkili bir şekilde geri kazanılmış ve kullanılan yapılardır (Lewis vd., 2007).

Sürdürülebilir ambalaj tasarımı, yeşil ambalajlama tasarımı ve çevre bilinci olan tasarım kavramları genel olarak çevre dostu ambalajlama kavramı ile benzer anlamda kullanıldığı anlaşılmaktadır. Çevre dostu ambalajlama konusu yalnızca endüstriyel boyutu ile değil tüketici boyutu ile de ele alınan bir konu olmuştur. Literatür incelendiğinde çevre dostu ambalajlama ve tüketici konulu çalışmaların yaklaşık yirmi yıllık bir geçmişi olduğu anlaşılmaktadır. Bu doğrultuda odaklanılan konular, çevre dostu ambalajların; tüketicilerin satın alma kararındaki etkisini ölçme (Monnot vd., 2015; van Birgelen vd., 2009; Rokka ve Uusitalo, 2008), tüketicilerin sosyodemografik ve psikografik özellikleri üzerindeki etkisini anlama (Prakash ve Pathak, 2017; Klaiman vd., 2016), belirsizlik ve algılanan risk faktörünün tüketici satın alma kararlarına etkisi (Koenig-Lewis vd., 2014) ve planlı davranış (TPB), nedenli eylem (TRA) (Prakash ve Pathak, 2017; Scott ve Vigar-Ellis, 2014; van Birgelen vd., 2009) ve anlam yükleme (Attribution) gibi teorilerin (Monnot vd., 2015) ilgili konu analiz edilirken ele alınan rasyonel değişkenler arasında sıralandığı görülmüştür.

\section{1. Çevre Dostu Ambalaj Özellikleri}

Ürünün oluşumundan başlayarak kullanım sonrasına kadar geçen her aşamasında bir ürün özelliği olan ambalajın hem toplum hem de tüketiciler üzerinde önemli etkileri bulunmaktadır. Tüketicilerin satın aldıkları ürünün geri dönüşümlü ya da çevre dostu özelliklere sahip olduğunu bilmesi, çevreye duyarlı bir birey olarak çevrenin sürdürülebilirliğine ve korunmasına sağladıkları için kendilerini iyi hissetmelerini sağlayacaktır. Yönetimsel olarak ele alındığında düşük çevresel etkiye ve karbon ayak izine sahip ambalajların kullanılması (Tamani vd., 2015; Scott ve Vigar-Ellis, 2014) çevre dostu ambalajlama konusundaki temel unsurları oluşturduğunu ifade etmek gerekir. Bir sonraki süreçte ambalajlama için kullanılacak malzemenin karar verilmesine gelir ki, ambalajın muhtevasının cam, alüminyum, plastik, karton, geri dönüşümlü kâğıt ya da diğer organik materyallerden oluşması çeşitli çalışmalara konu olmuştur (Klaiman vd., 2016; Koenig-Lewis vd., 2014; Magnier vd., 2016; Rokka ve Uusitalo, 2008).

Bu başlık altında ele alınan bir diğer husus da ürün üzerinde en az ambalajın kullanılması, hiç kullanılmaması ya da çok az plastik materyal kullanılması (Magnier ve Schoormans, 2015) konularına odaklanırken, ambalaj üretiminde yenilebilir enerjiden faydalanılması da irdelenmiştir (Jerzky, 2016). Büsser vd., (2008), ürünlerin genellikle onları korumak için kullanılan ambalajlardan çok daha yüksek bir doğal değere sahip olduğunu belirtmiştir. Yazarlara göre, düşük performans gösteren ambalajlama nedeniyle ortaya çıkan ürün kayıpları (bozulma, kırılma), çevre üzerinde, aşırı ambalaj indirgemesinden elde edilen kazançlardan çok daha büyük olumsuz etkilere neden olabilmektedir. Ürünün kullanım aşamasına gelindiğinde ise; ambalajın insan hayatına zarar vermeyecek şekilde zehirli unsurlardan (koku, tat vb.) arındırılmış materyallerden oluşmasının yanı sıra (Wan vd., 2015), elektrik ve su tüketiminin düşük olması (Banerjee, 2015; Hasan vd., 2012) önemli alt 
başlıklar olarak dikkat çekmektedir. Çevre dostu ambalajlama konusundaki son aşama ürün kullanımından sonra ortaya çıkmaktadır. Bu doğrulta literatürde ele alınan alt başlıklara baktığımızda; geri dönüşüm (Jerzyk, 2016; Klaiman et al., 2016; Martinho vd., 2015; Tamani vd., 2015), yeniden kullanılabilirlik (Scott ve Vigar-Ellis, 2014) ve biyo-bozunabilirlik (biodegradable) (Monnot vd., 2015; Scott ve Vigar-Ellis, 2014) kavramlarının ön plana çıktığı görülmektedir.

Yeşil uygulamalara katılan endüstriler çok çeşitli olabilmektedir. Konaklama hizmetleri, restoranlar, emlak hizmetleri, otomobil imalatçıları, sağlık ve eczacılık uygulamaları, profesyonel hizmetler ve en yaygın olarak da hızlı tüketim mallarını bu listeye dahil edebiliriz. DiPietro ve Gregory (2012) göre bir işletmenin yeşil olması, topluma çevre dostu ve çevreye daha az zarar veren sorumlu yöntemler kullanması şeklinde yorumlanmıştır. İşletmelerin faaliyetlerinde çevre dostu ambalajlama gibi yeşil uygulamalara yer vermesi, çevreye verilen zararı azaltmada etkilidir. Kaynakların koruması, geri dönüşüm programlarına katılmak, geri dönüştürülebilir ürünler oluşturmak ve ürünün kullanım ömrü boyunca zehirli kimyasal kullanımını ortadan kaldırmak öncelikli faktörler arasında sayılmaktadır (DiPietro, Gregory ve Jackson, 2013).

Dünyanın pek çok farklı noktasında yeşil ambalajlama ile ilgili uygulamalara rastlamak mümkündür. Örneğin Dell, Hindistan'da dizüstü bilgisayar ambalajlarında kullandığı malzemeleri çevre dostu olanlarla değiştirmiştir. Aynı şekilde Mcdonald's servis ambalajlarında geri dönüşümlü olanları tercih etmektedir. Hindistan menşeili MRF oto lastiği firması ürettiği MRFZSLK modeli lastiklerinde silis-bazlı kauçuk kullanarak çevre dostu uygulamalara katkı sağlamaktadır (Prakash ve Pathak, 2017). Bir başka küresel marka olan Nike da benzer şekilde çevre dostu uygulamalara yer vererek; ambalajlarında zehirli kimyasalları azaltmak, fiziksel atıkları ortadan kaldırmak, yeniden kullanımı ve geri dönüşümü teşvik etmek için faaliyetlerini ve süreçlerini sürekli olarak geliştirmektedir (Angeles, 2014).

Çevre dostu ambalaj özelliği taşıyan ürünlerin ve pazarlama uygulamalarının öneminin arttığı günümüzde, farklı sektörlerden örneklere rastlamak mümkündür. Plastik şişenin zararlarından ve plastik tüketiminin doğaya verdiği zarardan yola çıkarak PepsiCo, plastik tüketimine karşı Aquafina markalı suyunun ABD fastfood ve restoran zincirlerinde alüminyum kutularda satışa sunulacağını açıklamıştır. Biyodevrim niteliğinde olduğu ifade edilen bir diğer çevre dostu ambalaj uygulaması ise SCOBY adını taşıor. SCOBY ambalaj olarak kullanıldıktan sonra yenilebiliyor veya tohum olarak da kullanılabiliyor. Her bir ambalaj, tamamen yerel tarımsal atıklardan elde ediliyor ve bu da \%100 oranında gübrelenebilir olduğu anlamına geliyor. Tek kullanımlık plastik sorununa sürdürülebilir bir çözüm sunan SCOBY gündelik yaşamda kullanılan plastiğin tüm özelliklerini barındırıyor (Üçhisarlı, 2019).

Ülkemizde de çevre dostu ambalaj kullanımına gerek sivil toplum kuruluşları tarafından gerekse de devlet nezdinde geliştirilen yasa ve yönetmeliklerle destekler verilmektedir. Bu bağlamda geliştirilen "Sıfır Atık" projesi kapsamında 2018 yılı başından itibaren bir yıllık dönemde kaynağından toplanarak geri kazanılan atık miktarı 2,2 milyon ton ambalaj atığı olarak belirlenmiştir (Skylife, 2018). Bir ton plastik atık dönüşümü sayesinde $41 \mathrm{~kg}$ daha az sera gazı çevreye salınmakta, $5774 \mathrm{KWh}$ enerji tasarrufu sağlanmakta ve 2,3 kat depolama alanı kazanılmaktadır. Bir ton kâğıt atık dönüşümü sayesinde ise $177 \mathrm{~kg}$ daha az sera gazı çevreye salınmakta, $4100 \mathrm{KWh}$ enerji tasarrufu sağlanmakta 17 ağaç kurtulmakta ve 2,5 kat depolama alanı kazanılmaktadır (https://sifiratik.gov.tr/). Bu veriler çevre dostu ambalaj kullanımının ne kadar önemli ve gerekli olduğunu hem tüketiciler hem de üreticiler bağlamda ortaya koymaktadır.

\section{2. Çevre Dostu Ambalaj ve Farkındalık}

Yeşil pazarlama kapsamındaki çevre dostu uygulamalardan etkilenen en önemli unsurlarında biri şüphesiz tüketicilerdir. Postmodern pazarlama ve tüketim anlayışının yayılmasıyla birlikte, tüketiciler sadece kişisel hazzı ön plana alarak tüketmek için değil, satın aldıkları ürünün; üretim sistemleri, doğal kaynak etkinliği, çevreye karşı duyarlılığı ve zararlı atık konularına da dikkat etmeye başlamışlardır. Yeşil tüketici olarak adlandırılan bu tüketiciler, çevre dostu ürünler kullanarak, çevreyi etkileyen zararlı toksinlerin azaltılmasına yardımcı olan basit günlük ürünler satın alırlar. Diğer bir deyişle, işlenmemiş kaynakların verimli kullanımı ve çevrenin korunması, yeşil ürün tüketimine duyulan isteği de arttırmaktadır (Morel ve Kwakye, 2012).

Ürün boyutunun en görünür öğelerinden biri olan ambalajlama, yeşil pazarlama faaliyetlerinin de odak noktasındadır. Tüketici davranışı alanındaki pek çok çalışma ambalajlamanın tüketici algısındaki yerini konu alır. Magnier ve Crié (2015), ambalajlama ile ilgili literatürün, bütünsel ve analitik olmak üzere iki ana 


\section{B. Özsaçmac1 - H. Özdemir 12/3 (2020) 2682-2701}

yaklaşıma ayrıldığını ifade etmişlerdir. Bütünsel yaklaşım, ambalajı bir bütün olarak ele almakta ve özelliklerini bağımsız olarak dikkate almamaktadır. Bu alanda yapılan bazı çalışmalar tüketicilerin paketleme algılarını ele almak için nitel yaklaşımlar kullanmıştır (Kniazeva ve Belk, 2007; Underwood ve Ozanne, 1998). Öte yandan, analitik yaklaşım ambalajlama özelliklerine bağımsız olarak bakmaktadır ve literatürde genel olarak incelenen unsurlar yapısal, görsel ya da sözel olabilir. Bazı çalışmalar, ürün değerlendirme ve satın alma niyetini (Kauppinen ve Luomala, 2010) veya inanç ve tüketicilerin tutumlarını etkilediğini bulmuştur (Wilke vd., 2011). Ambalajlama alanındaki az sayıda çalışma çevresel etki üzerine odaklanmıştır (Rokka ve Uusitalo, 2008). Araştırmacılar, yaptıkları analizlerinin sonuçlarına göre, ürün paketlemesinin tüketici seçiminde önemli bir ürün özelliği olduğunu ifade etmişlerdir.

Literatüre bakıldığında ekolojik kaygı kavramını ön plana çıkaran pek çok çalışmanın olduğu görülür. Çevre yanlısı yaklaşımların bireysel olarak olumlu manada bu kavramdan beslendiği ifade edilmiştir. Giannelloni (1998), bireysel ekolojik kaygının öncüllerini; cinsiyet ve gelir değişkenlerini içeren sosyo-demografik yapı ve tüketici etkinliği, deneyim, değerler, öz-yönetim ve yardımseverlik gibi değişenleri kapsayan psiko-sosyolojik yapılar ile açıklamaya çalışmıştır. Boks ve Stevels (2007) ise, çevre dostu ambalaj faaliyetlerini devlet, bilimsel ve tüketici tabanlı olmak üzere üç farklı kategori çerçevesinde ele almıştır. Burada devletin çevre dostu olması, tehlikeli maddelerin geri dönüştürülmesi veya atılması gibi yasal düzenlemeleri kapsarken, bilimsel uygulamalar genellikle yaşam döngüsüne ilişkin değerlendirmeleri göz önüne alır ve ürünlerin tüm ürün yaşam döngüsü boyunca çevresel etkilerini belirlemektedir. Bu kategori genellikle bir ürünün gerçek çevresel etkisini ölçmek için kullanılacak en doğru ve tarafsız bakış açısı olarak kabul edilir. Son olarak, tüketici kategorisi ise, bu çalışmada da olduğu gibi ambalajı, tüketicilerin çevre dostu olma algılarını ele almaktadır.

van Birgelen vd., (2009), araştırmalarında, içecekler için çevre dostu satın alma ve elden çıkarma kararlarının, tüketicilerin çevre bilinciyle ve çevre dostlarıyla ilgili olduğunu bulgulamış ve tüketicilerin, tat ve fiyat değişkenleri hariç, çevre dostu içecek ambalajları lehine, hemen hemen tüm ürün niteliklerini değiştirmeye istekli olduklarını ortaya koymuşlardır. Koenig-Lewis vd., (2014), tüketiciler üzerinde çevre dostu ambalajlamanın duygusal ve rasyonel değerlendirmelerini araştırmış ve satın alma niyetinin genel çevresel kaygılardan önemli ölçüde etkilendiğini, ancak faydaların rasyonel değerlendirmelerinden etkilenmediğini göstermiştir. Yazarlar, bu bilişsel faydaların, olumlu ve olumsuz olarak hem duygular hem de davranışsal niyet üzerinde önemli doğrudan etkilere sahip olduğunu vurgulamışlardır.

Mainieri vd., (1997), insanların çevresel (geri dönüşüm bilinci gibi) hassasiyetlere sahip olmasının, ürün ambalajının çevresel etkileri konusunda bir farkındalık oluşturabileceğini ifade etmiştir. İşletmeler çevre dostu bir ürün hakkında farkındalık geliştirirken, satın alma davranışını etkilemek için ürünün tüketici ve çevresel özellikleri hakkındaki bilgilerini artırmaya çalışırlar. Bu farkındalığın oluşması, işletmelerin çevre dostu ambalajlı ürünler geliştirmeleri ve bunun tüketiciler tarafından talep görmesi noktasında oluşabilecek direnci de bertaraf edebilecektir (Yacoob ve Zakaria, 2011). Noor vd., (2016), araştırmalarında, tüketicilerin çevre farkındalığı ve çevre kalitesinin bozulmasına yönelik algısının, çevre dostu tutum sergilemelerine ve bunun da satın alma faaliyetlerini çevre dostu ürünlere dönüştürdüğünü ifade etmişlerdir.

\section{3. Çevre Dostu Ambalaj İçin Ödeme İsteği}

Ödeme isteği (Willingness to Pay-WTP) kavram olarak baktığımızda tüketicilerin bir ürünü satın almak için ödemeye razı olduğu miktarı tanımlamaktadır. Tüketicilerin ödeme isteği; belli miktardaki soyut ya da somut bir değere alıcıların ödemek istediği maksimum fiyat seviyesidir. Alıcının almak istediği miktara tahsis ettiği sübjektif değerin oran ölçekli bir ölçütüdür. Tüketici ürünü, ödeme isteğinin satın alma fiyatını aştığı, bir dizi alternatif ürün arasından tercih eder (Wertenbroch ve Skiera, 2002, s.228).

Herhangi bir alanda bireylerin ileride oluşacak tercihlerinin belirlenmesinde değişik yöntemler izlenebilmektedir. Sanal tercih (Stated Preference, SP), gerçekçi tercih (Revealed Preference, RP) ve Konjoint analizi (Conjoint Analysis) yöntemleri tercih belirlemede kullanılırlar (Ben-Akiva vd., 1994). Breidert vd., (2006), ödeme isteğinin ölçümünde kullanılacak sınıflandırmayı sanal ve gerçekçi tercih olmak üzere iki boyutta ele almışlardır. Gerçekçi tercih yöntemleri, davranışları en üst düzeye çıkarmaya yardımcı olduğunu varsaymakta ve bireylerin nasıl seçim yaptıklarını analiz ederek tüketicilerin tercihlerinden sonuçlar çıkarmaktadır. Gerçekçi tercihi kullanan çalışmalar, doğal ve tasarlanmış deneyler dahil olmak üzere, bireyler tarafından yapılan seçimleri sıklıkla analiz eder. Sanal tercih yöntemleri ise, bireylerin neyi seçeceğini ortaya çıkarmak için mülakat sorularına ve anketlere verilen cevapları kullanır. Sanal tercih metotları genellikle 
eleştirilen yöntemler arasındadır, bunun nedeni varsayımsal önermelere bağlı olarak yanlılığa (biased) eğilimli olmaları ve gerçek dünya koşullarını mükemmel bir şekilde yansıtamadıklarına yönelik gözlemlerdir. Sonuç olarak, gerçekçi tercihler tipik olarak tercih edilir çünkü bireyin gerçek tercihlerini daha doğru bir şekilde yansitırlar.

\subsection{Satın Alma Niyetini Etkileyen Çevre Dostu Ambalaj Değişkenleri}

Satın alma niyeti değişkeni pazarlama literatüründeki pek çok çalışmada ana değişkenlerden biri olmuştur. Yapılan bir araştırmada (Ozsacmaci, 2018), yeşil pazarlama faaliyetlerinin yeşil marka farkındalığı ve tüketici satın alma niyeti üzerindeki aracılık etkisi incelenmiş yeşil pazarlama uygulamalarının çeşitliliği ve tüketicinin bu uygulamalara karşı tutumunun satın alma niyeti üzerinde önemli bir etkiye sahip olduğu gözlenmiştir. Literatüre bakıldığında çevre dostu ambalaj özelliklerini etkileyen pek çok çevresel faktörün olduğu gözlenmektedir. Önceki bölümlerde değindiğimiz ve bu çalışmanın da kavramsal modelini oluşturan; çevresel tutum, fiyat, tasarım, algılanan kalite, beklenen fayda ve bilgi birikimi değişkenleri alt başlıklar halinde bundan sonraki bölümlerde ele alacağız.

\subsection{1. Çevresel Tutum}

Literatürde tüketicilerin satın alma davranışlarını etkileyen önemli değişkenlerden biri de tutum kavramıdır. Tutumlar tüketicilerin ürün tercihlerine yansıdığı gibi son dönemlerde özellikli olarak ambalaj tercihlerinde de rol oynamaktadır. Ambalajlama tüketicinin satın alma anındaki odaklanmasında devreye girerek satın alma kararını etkileyebilmekte ve tüketiciyi rakip markalar arasında bir seçim yapmaya yönlendirmektedir (Jerzyk, 2016). Yapılan birtakım araştırmalar (Hidalgo-Baz vd., 2017) ürün imalatçılarının ambalajlama kararlarında tüketici tercihlerinin önemli bir yer tutması ve ürünün başarısı açısından da oldukça belirleyici olduğu ifade edilmiştir.

Çevresel tutum, bireyin, özellikle çevresel davranışa ilişkin olarak ortaya koyduğu performansına bağlı olumlu ya da olumsuz değerlendirmesini ifade eder (Maichum vd., 2017). Gerekçelendirilmiş Eylem Teorisi (TRA) kapsamında da ele alındığı gibi, Ajzen ve Fishbein (1980), bireyin tutumunun davranışsal niyetleri üzerinde doğrudan etkileri olduğunu ve bu bağlamda da çevresel tutumun, tüketicilerin çevre dostu ürünlere yönelik satın alma niyetini tahmin etmede önemli değişkenlerden biri olduğunu ifade etmiştir.

Tüketicilerin tercih ettiği çevre dostu olmayan ambalajlar ve geri dönüştürülemeyen plastik ambalajlar, ürünün kullanımına karşı olumsuz bir tutum yaratmıştır. Önceki çalışmalar, çevre dostu ambalajlanmış ürünlere yönelik tüketici tutumunun satın alma niyetini etkilediğini göstermektedir (Limbu ve diğerleri, 2012). Cheah ve Phau (2011), çevre dostu ürünlere karşı olumlu tutum sergileyen tüketicilerin bunları satın almak için daha fazla istekli olduklarını bulgulamıştır. Bu noktadan hareketle çevre dostu ürünlere karşı oluşan bu olumlu tutumun çevre dostu ambalajlı ürünlere yansıması da olumlu olacaktır.

\subsubsection{Bilgi Birikimi}

Karatu (2015)'ya göre bilgi birikimi, tüketicilerin bilgileri bulma yeteneği ve belirli ürün grupları hakkında sahip olduğu bilgi miktarıdır. Alavi ve Leidner (2001) ise bilgi birikimini, bireyin etkin eyleme geçme kapasitesini artıran haklı kişisel inanç olarak tanımlamıştır. Bu çalışma özelinde yorumlamak gerekirse, çevre dostu ambalajlama ile ilgili bilgi birikimi, tüketicilerin "yeşil" kavramı ile ilgili sahip oldukları bilgileri nasıl yorumladıklarıyla doğru orantılıdır. Tüketicilerin yeşil ürünler satın alma konusundaki tutumları, ömürleri boyunca biriktirdikleri yeşil ürünler kavramına yönelik inanç ve bilgilerinden oluşmaktadır. Çevre bilgisi ise, doğal çevre ve onun ana ekosistemleri ile ilgili gerçekler, kavramlar ve ilişkiler hakkında genel bir bilgi olarak tanımlanabilir. Çevre dostu ambalaj ürünüyle ilgili tüketici ne kadar fazla bilgi sahibi olursa, bu ürünlere yönelik satın alma niyetini de o kadar artıracak olan olumlu görüş o kadar fazla olacaktır. Bu bağlamda tüketici algısı da bilgi ile bağlantılıdır ve tüketicilerin satın alma faaliyetlerini belirlemelerine yardımcı olan önemli bir araçtır.

\subsubsection{Fiyat}

Yeşil ürünler için geliştirilecek fiyatlandırma stratejisi konvansiyonel ürünlerden farklı olarak, katlanılan ek maliyetler de göz önüne alındığında daha üst seviyede belirlendiği anlaşılmaktadır. Diğer taraftan fiyat, tüketici satın alma niyetini ve kararını etkileyen önemli stratejik kararlardan biridir. Morel ve Kwakye (2012), ürün satın alma kararında kalite ve fiyat arasında bir ilişki olduğunu ifade etmiştir. Çevre dostu ambalajlı 
ürünün, pazarda pahalı bir ürün olarak bilinmesinin nedenleri arasında; ürün güvenliği prosedürleri, yüksek kalite standartları ve çevre kriterlerine daha fazla dikkat edilmesi sayılmaktadır (Royne vd., 2011). Fiyatı yükselten bir diğer neden olarak talep eksikliği de gösterilebilir. Bunların yanı sıra Creyer (1997), tüketicilerin yeşil ambalajlı ürün için daha yüksek bir fiyat ödemeye istekli olmalarını, şirketin "yeşil" seçimlerinden dolayı bir ödüllendirme davranışı şeklinde yansıdığını ifade etmiş̧ir.

\subsubsection{Beklenen Fayda}

Yeşil ürünlerin ve yeşil organizasyonların rekabetçi bir ortamdaki potansiyel faydaları önemli bir tartışma konusudur. Çevre dostu satın alma davranışının benimsenmesinde sağlık, güvenlik, sembolizm ve statü gibi bir dizi faydanın rolü büyüktür (Ottman, vd., 2006). Bu alandaki araştırmalar çevre dostu ambalajlı ürünlerde kullanılan yeşil teknolojinin sadece çevreye değil, aynı zamanda tüketici ve ekonomiye, yeni ürünler ve pazarlar geliştirerek fayda sağladığı ifade edilmektedir (Drozdenko, vd., 2011). Magnier ve Crié (2015:359), yaptıkları çalışmada algılanan fayda değişkeni bireysel ve pro-sosyal fayda olmak üzere iki boyutta (Thogersen, 2011) ele almıştır. Bireysel/özel fayda kapsamında; sağlık, elverişli olma (ambalaj azalmasına bağlı olarak), fiyatta düşme (ambalaj azalmasına bağlı olarak), sosyal değer (çevre dostu ürün satın alma) ve duygusal değer (daha iyi birey olma) değişkenleri incelenmiştir.

\subsubsection{Algilanan Kalite}

Algılanan kalite, bir ürünün kalitesine ilişkin genel tüketici algısını ifade etmekte ve aynı zamanda rakip ürünler karşısında tüketicilerin bir ürünün üstünlüğüyle ilgili genel yargılarını temsil etmektedir. Ayrıca, algılanan kalite ve satın alma niyeti değişkenlerinin pozitif bir korelasyona sahip olduğu ifade edilmiş, algılanan kalitenin satın alma niyetini öngörmede kullanabileceği belirlenmiştir (Tsiotsou, 2006). Bazı araştırmalar (Shahira vd., 2016), tüketicilerin yüksek ürün kalitesini algıladığında, daha güçlü bir şekilde tekrar alım niyetinde olacaklarını göstermektedir. Agyeman (2014)’a göre kalite, çevresel kaygının ve fiyat değişkenlerinden sonra tüketici satın alma niyetini etkileyen üçüncü en önemli değişken olarak ifade etmiştir. Ürün ambalajının kalitesi ise, ürünün kalitesini temsil eden önemli bir ürün boyutudur. Johnson ve Ettlie (2001), performansın sonucu olarak ortaya çıkan ürün kalitesini, kişiselleştirme ve hatalardan arınma derecesi olarak etiketlenebileceğini ve aynı zamanda ürünün müşteri gereksinimlerini karşılama derecesinin bir yansıması olarak ifade etmiştir.

\subsubsection{Tasarım}

Ürün ambalajı sahip olduğu birtakım özelliklerinden dolayı satışı arttıran ve kolaylaştıran bir ürün boyutu olarak kabul edilebilir. Bu özelliklerinden biri de ürünü tüketici gözünde daha çekici hale getirerek, ürün imajına katkı sağlayan ambalaj tasarımıdır. Tasarım konusu çevre dostu ambalajlama kapsamında ele aldığımızda karşımıza eko-tasarım ambalaj kavramı (Holdway, vd., 2002) çıkmakta ve kaynak azaltma, yeniden kullanma, geri dönüşüm ve atık giderme gibi özellikleriyle tanımlanmaktadır. Magnier ve Crie (2015)'de eko-tasarım konusunu ekolojik ipuçları değişkenleri ile incelemiş ve yapısal ipuçları (malzeme, boyut, şekil gibi), grafiksel / ikonik ipuçları (renkler, görseller gibi) ve bilgilendirme ipuçları (çevresel etiket, sertifikalar, izinler gibi) olmak üzere üç kategoriye ayırmıştır. Ayrıca araştırmacılar, tüketicilerin eko-tasarıma sahip ürünlere olumlu tepkiler verdiği ve işletmelerin eko-tasarımlı ambalaj kullanımı ile markalarında rekabetçi üstünlük elde edebileceklerini bulgulamışlardır. Çevre dostu ambalajların tasarımı ve tarzı tüketiciler tarafından satın alım miktarında artışa yol açabilmektedir. Aksi takdirde talep ve farkındalık eksikliği nedeniyle, çevre dostu ambalaj kullanımı işletmeler için yüksek maliyetlere neden olmaya devam edebilecektir (Barbara, 2012).

\section{Araştırma Metodolojisi}

$\mathrm{Bu}$ araştırmanın amacı, çevre dostu ambalajlı market ürünlerine ait fiyat, tasarım, algılanan kalite, çevresel tutum, beklenen fayda ve bilgi birikimi değişkenlerinin tüketicilerin tutumlarına, farkındalıklarına ve satın alma niyetlerine olan etkisini ortaya koymaktır. Mevcut literatür incelendiğinde, genel olarak geçmiş çalışmalara konu olan değişkenler saptanmış ve araştırmaya dahil edilmiştir. Buna göre; fiyat (Morel, 2012; Van Birgelen vd., 2009), tasarım (Magnier ve Crie, 2015), algilanan kalite (Chang ve Fong, 2010; Tsiotsou, 2006), Çevresel Tutum (Prakash ve Pathak, 2017; Maichum vd., 2016; ; Kim vd., 2013; Han vd., 2009), Beklenen Fayda (Magnier ve Crie, 2015; Thogersen, 2011; Ottman vd., 2006) ve bilgi birikimi (Koenig-Lewis vd., 2014; Alavi ve 
Leidner, 2011) değişkenleri, çevre dostu ambalajlı market ürünlerine etkisi incelenecek olan bağımsız değişkenler olarak belirlenmiştir.

$\mathrm{Bu}$ çalışma nicel verilere dayalı genel tarama modelinde (betimsel) uygulamalı bir araştırma örneği sunmaktadır. Betimsel araştırmalar geniş bir uygulama alanına hitap etmesinin yanı sıra nesnelerin, tüketicilerin, toplulukların ve çevrelerin özelliklerini tarif etmektedir. Amaç bir problemi ya da mevcut durumu anlamaya, tanımaya ya da tahmin etmeye yöneliktir (Nakip ve Yaraş, 2017:52). Araştırma kapsamında tüketicilerin çevre dostu ambalaj özelliklerini niteleyen çeşitli değişkenlerin (fiyat, tasarım, algılanan kalite, beklenen fayda, çevresel tutum ve bilgi birikim) tüketicilerin çevre dostu ambalajlı ürünlere yönelik tutum ve satın alma niyetleri üzerindeki etkisinin analiz edilmesini hedeflenmektedir. Bunların yanı sıra tüketicilerin çevre dostu ambalajlama konusundaki farkındalık seviyelerini de ortaya koymak hedeflenmiştir.

\subsection{Veri Toplama Yöntemi ve Örneklem}

Araştırmaya veri toplamak amacıyla nicel veri toplama yöntemlerinden anket yöntemi tercih edilmiştir. Anket verileri, onlineanketler.com adresi aracılığıyla 02.12.2019 tarihinden itibaren iki ay süreyle toplanmış ve tasnif edilmiştir. Gözlem ve diğer nitel yöntemler ile karşılaştırıldığında, anket yöntemi önemli miktarda verinin ekonomik ve etkili bir yolla toplanabilmesini sağlar ve genellikle büyük örneklem hacmi gerektirir (Burns ve Bush, 2015: 144).

$\mathrm{Bu}$ çalışmada ele alınan değişkenler; fiyat, tasarım, algılanan kalite, çevresel tutum, beklenen fayda, bilgi birikimi, çevre dostu ambalajlı ürünlere yönelik tutum ve satın alma niyeti olarak belirlenmiştir. Bu noktadan hareketle veri toplamak amacıyla hazırlanan anket tasarımı da yapısal olarak literatür taramasında yer alan ölçeklere dayanmaktadır. Tablo 1'de araştırmada kullanılan değişkenler, bu değişkenleri ölçmek için kullanılan ifadeler ve ölçeklerin uyarlandığı kaynaklar sıralanmaktadır. Uyarlanan ölçeklerde market ürünleri kategorik olarak belirlenmiş ve deneklere yöneltilen sorularda herhangi bir marka ya da kurum adı ön plana çıkarılmamıştır. Geliştirilen anket soruları içerisinde yaş, cinsiyet, gelir durumu ve eğitim durumundan oluşan demografik faktör sorularının yanı sıra, ana ölçek ifadelerinin yer aldığ $5^{\prime}$ li Likert-tipinde sorular da kullanılmıştır. Ankete katılan deneklerden ifadelere katılma derecelerini,1: Kesinlikle Katılmıyorum ile 5: Kesinlikle Katılıyorum aralığında değerlendirmeleri istenmiştir. Bu sorulara ek olarak; deneklerin alışveriş sıklı̆̆1 ve sektör sıralama tercihlerinin ölçüldüğü soru tipleri de mevcuttur. Toplanan veriler uygun şekilde kodlandıktan sonra SPSS 21.0 istatistik programı kullanılarak tasnif ve analiz edilmiştir.

Araştırmaya dahil edilecek örneklemi belirlemek amacıyla, olasılıksız örnekleme yöntemlerinden kolay ulaşılır (kolayda) örnekleme yöntemi benimsenmiş ve bu işlem için çevrimiçi anket uygulaması yürütülmüştür. Kolay ulaşılır örnekleme yaklaşımı, potansiyel katılımcı kişiler arasında kişisel seçme mantığına dayanır (Daşdemir, 2016:291). Çevrimiçi anketin kullanılmasında amaç tüketicilere ulaşım konusunda hız ve kolaylık sağlarken, aynı zamanda maliyet avantajı ve verilerin analiz programına aktarılmasını da daha elverişli kılmaktadır.

Araştırmanın evrenini Türkiye'de yaşayan 17 yaş ve üzeri tüketiciler oluşturmaktadır. Hedef ana kütleden seçilecek olan örneklem büyüklüğünün tespitinde literatürde kabul görmüş ve sıklıkla kullanılan değerler üzerinde durulmuştur. Bu noktadan hareketle; yapılan hesaplamalar sonucunda (Nakip ve Yaraş, 2017:289), ana kütleye 0,05 örneklem hatasında, \%95 güvenilirlik düzeyinde çıkan örneklem büyüklüğü minimum 384 olarak tespit edilmiştir. Örneklemin ana kütleyi temsil edebilmesini sağlamak amacıyla elde edilmesi düşünülen değerlerin üzerinde bir örneklem büyüklüğü olarak 450 seçilmiş, bunlardan da 401 tanesi incelenerek araştırmaya dahil edilmiştir.

Bu çalışmada kullanılan ölçeklerin güvenilirliğinin test edilebilmesi için Cronbach Alfa Analizi yapılmış, $\alpha$ katsayı değerleri hesaplanmıştır. İç tutarlılık katsayısı olarak da nitelenen Cronbach Alfa $(\alpha)$ değerlerinin kabulü için sınır değer olan 0,60'tan yüksek olması istenen bir durumdur (Nakip ve Yaraş, 2017:196). Araştırmada kullanılan ölçeğin alfa değeri 0,929 olarak hesaplanmıştır. Buna göre, ölçeğin yüksek derecede güvenilir olduğunu söylemek mümkündür.

Araştırma için geliştirilen hipotezlerin analizinde, T-testi, ANOVA ve Çoklu Regresyon analizleri kullanılmıştır. İnternet ortamında elde edilen veriler, gerekli kodlama ve veri temizliği yapıldıktan sonra paket programa aktarılmıştır. 
B. Özsaçmac1 - H. Özdemir 12/3 (2020) 2682-2701

Tablo 1. Değişkenler ve İfadeler

\begin{tabular}{|c|c|c|}
\hline Değişkenler & Ölçekler & İfadeler \\
\hline Bilgi Birikimi & $\begin{array}{l}\text { - Koenig-Lewis vd., } \\
2014 \\
\text { - Alavi ve Leidner, } \\
2011\end{array}$ & $\begin{array}{l}\text { - Günlük yaşantımda çevresel sorunlara karşı } \\
\text { duyarlıyım. } \\
\text { - Çevre sorunları hakkında çok bilgiliyim. } \\
\text { - Ürün paketlerindeki çevresel ifadeleri ve sembolleri } \\
\text { anlıyorum. } \\
\text { - Çevreye zarar vermeyen ekolojik ürünler } \\
\text { kullanıyorum. }\end{array}$ \\
\hline Tasarım & $\begin{array}{l}\text { - Magnier ve Crie, } \\
2015\end{array}$ & $\begin{array}{l}\text { - Çevre dostu bir şekilde ambalajlanmış ve geri } \\
\text { dönüşüm için kolaylaştırılmış yeşil ürünler satın alma } \\
\text { ihtimalim daha yüksektir. } \\
\text { - Çevre dostu ambalajlı ürünü renginden ve üzerindeki } \\
\text { görsellerden tanırım. }\end{array}$ \\
\hline Algılanan Kalite & $\begin{array}{l}\text { - Chang ve Fong, } \\
2010\end{array}$ & $\begin{array}{l}\text { - Tüketicilerin çevresel beklentilerinin karşılanması bir } \\
\text { kalite göstergesidir. } \\
\text { - Çevre dostu ambalajlı ürünün kalitesi yüksektir. } \\
\text { - Çevre dostu ambalajlı ürünlerin kalitesine diğer } \\
\text { ürünlere göre daha çok güvenirim. }\end{array}$ \\
\hline
\end{tabular}

\begin{tabular}{|c|c|c|}
\hline Çevresel Tutum & $\begin{array}{ll}\text { - } & \text { Han vd., } 2009 \\
\text { - } & \text { Kim vd., } 2013 \\
\text { - } & \text { Maichum vd., } 2016\end{array}$ & $\begin{array}{l}\text { - Çevre dostu ürünler yaygınlaşmalıdır. } \\
\text { - Çevre dostu ambalaj kullanımı çevre için iyidir. } \\
\text { - Çevre dostu ürünlere karşı olumlu bir tutuma sahibim. }\end{array}$ \\
\hline Beklenen Fayda & $\begin{array}{l}\text { - Magnier ve Crie, } \\
2015 \\
\text { - } \quad \text { Thogersen, } 2011 \\
\text { - Ottman vd., } 2006\end{array}$ & $\begin{array}{l}\text { - Çevre dostu ambalajlı ürünlerin daha sağlıklı } \\
\text { olduğunu düşünüyorum. } \\
\text { - Çevre dostu ambalajlı ürünlerin doğal kaynakların } \\
\text { korunmasında katkı sağladığını düşünüyorum. } \\
\text { - Çevre dostu ambalajlı ürünler kullandığımda kendimi } \\
\text { daha iyi bir birey olarak görüyorum. }\end{array}$ \\
\hline
\end{tabular}

Fiyat

- $\quad$ Morel, 2012

- Van Birgelen vd., 2009
- Çevre dostu ambalajlı ürünler satın almamda fiyat faktörü belirleyicidir.

- Çevre dostu ambalajlı ürün fiyatının yüksek olması ürünün kalitesinin yüksek olduğunu gösterir.

$\begin{array}{lll}\begin{array}{l}\text { Daha Fazla } \\ \text { Ödeme İsteği ve }\end{array} & \bullet & \text { Wee vd., } 2014 \\ \begin{array}{l}\text { Satın Alma } \\ \text { Niyeti }\end{array} & \bullet & \text { Kim vd., } 2013 \\ & & \begin{array}{l}\text { Wertenbroch ve } \\ \text { Skiera, } 2002\end{array}\end{array}$

Çevre Dostu

Ambalajlı
- Çevre dostu ambalajlı ürünler almayı tercih ederim.

- Normal ürünlerden daha pahalı olsalar bile çevre dostu ambalajlı ürünler satın alırım.

- Olumlu çevresel katkısı nedeniyle bir dahaki sefere çevre dostu ambalajlı ürünler satın almak istiyorum.

- Çevre dostu ambalajlı ürünler almaya gayret ederim. 
B. Özsaçmac1 - H. Özdemir 12/3 (2020) 2682-2701

$\begin{array}{llll}\begin{array}{l}\text { Ürünlere Yönelik } \\ \text { Tutum }\end{array} & \text { Han vd., 2009 } & \text { Magnier ve Crie, } & \begin{array}{l}\text { Çevre dostu ambalajlı ürünler kullandığımda kendimi } \\ \text { çevreye karşı daha sorumlu bir birey olarak } \\ \text { görüyorum. }\end{array} \\ & 2015 & \begin{array}{l}\text { Çevre dostu ambalaj kullanımı çevrenin korunması } \\ \text { için gereklidir. }\end{array}\end{array}$

\subsection{Araştırmanın Hipotezleri}

Araştırmada, çevre dostu ambalajlı market ürünlerine ait (fiyat, tasarım, algılanan kalite, çevresel tutum, beklenen fayda ve bilgi birikimi) değişkenlerin tüketicilerin tutumlarına, farkındalıklarına ve satın alma niyetlerine olan etkisini ortaya koymak ve tutumlarının çeşitli demografik faktörlere göre fark gösterip göstermediğini görmek amacıyla sekiz hipotez geliştirilmiştir.

Hı: Fiyat, tasarım, algılanan kalite, çevresel tutum, beklenen fayda ve bilgi birikimi değişkenleri tüketicilerin çevre dostu ambalajlı ürünlere yönelik tutumlarını olumlu etkiler.

$\mathrm{H}_{2}$ : Fiyat, tasarım, algılanan kalite, çevresel tutum, beklenen fayda ve bilgi birikimi değişkenleri tüketicilerin çevre dostu ambalajlı ürünleri satın alma niyetlerini olumlu etkiler.

$\mathrm{H}_{3}$ : Çevre dostu ambalajlı ürüne yönelik tutum tüketicilerin satın alma niyetini olumlu etkiler.

$\mathrm{H}_{4}$ : Çevre dostu ambalajlı ürüne yönelik farkındalık durumu satın alma niyetini olumlu etkiler.

$\mathrm{H}_{5}$ : Çevre dostu ambalajlı ürüne yönelik tutum cinsiyete göre anlamlı bir farklılık gösterir.

$\mathrm{H}_{6}$ : Çevre dostu ambalajlı ürüne yönelik tutum gelir durumuna göre anlamlı bir farklılık gösterir.

H7: Çevre dostu ambalajlı ürüne yönelik tutum yaşa göre anlamlı bir farklılık gösterir.

H8: Çevre dostu ambalajlı ürüne yönelik tutum eğitim düzeyine göre anlamlı bir farklılık gösterir.

\subsection{Araştırmanın Kısıtları}

Araştırmanın en büyük kısıdını örneklem türü ve büyüklüğü oluşturmaktadır. Anketin kolay ulaşılabilir örnekleme yaklaşımı sonucunda ortaya çıkan sınırlı gruba uygulanmış olması, elde edilen verilerin genellemesini güçleştirmektedir. Bu doğrultuda, araştırmanın sonuçlarının sadece anket uygulamasının yapıldığı kitle ile sınırlı kaldığı yorumunu yapmak mümkündür. Ayrıca, araştırmaya sadece market ürünlerinin dahil edilmesi, çevre dostu ambalaj kullanan diğer sektörlerin çalışma kapsamı dışında bırakılmasına neden olmaktadır. Bunların yanı sıra, zaman kısıdından dolayı, araştırma kapsamında anket uygulanan kitlenin yeşil pazarlama faaliyetleri ya da çevre dostu ambalajlama konusunda eşit bilgi ve ilgiye sahip oldukları varsayılmaktadır, bu da çalışmaya ilişkin önemli bir kısıt oluşturmaktadır.

\section{Araştırmanın Bulguları}

Araştırma kapsamında ankete katılan bireylerin sosyo-demografik profillerine baktığımızda (Tablo 2), katılımcıların \%56,4'ünün kadın, \%43,1'inin ise erkeklerden oluştuğu görülürken, katılımcıların büyük bir çoğunluğunun 26-34 ve 35-43 yaş aralığında $(\% 60,6)$ kümelendiği belirlenmiştir. Katılımcıların eğitim düzeylerine baktığımızda ise lisans seviyesinde eğitime sahip olanların $(\% 59,1)$ diğer eğitim seviyelerine göre baskın olduğu söylenebilir. Katılımcıların gelir düzeyinde; 8000TL $(\% 33,7)$ ve üzeri gelire sahip bireyler ön plana çıkarken bunu 4000-5999TL $(\% 27,2)$ gelire sahip bireylerin takip ettiği gözlenmiştir. 
B. Özsaçmac1 - H. Özdemir 12/3 (2020) 2682-2701

Tablo 2. Demografik Analiz Değerleri

\begin{tabular}{ccc}
\hline Yaş grupları & n & \% \\
\hline $17-25$ & 58 & 14,5 \\
$26-34$ & 109 & 27,2 \\
$35-43$ & 134 & 33,4 \\
$44-51$ & 53 & 13,2 \\
$52-59$ & 35 & 8,7 \\
60 ve üzeri & 12 & 2,7 \\
\hline Cinsiyet & & \\
\hline Kadın & 227 & 56,4 \\
Erkek & 174 & 43,1 \\
\hline Eğitim Düzeyi & & 7,0 \\
\hline Lise ve altı & 28 & 17,5 \\
Ön Lisans & 70 & 59,1 \\
Lisans & 237 & 16,2 \\
Lisansüstü & 66 & \\
\hline Gelir Düzeyi & & 3,5 \\
\hline $0-1999 T L$ & 14 & 15,7 \\
2000-3999TL & 63 & 27,2 \\
4000-5999TL & 109 & 18,7 \\
6000-7999TL & 75 & 33,7 \\
8000TL ve üzeri & 140 & $\mathbf{1 0 0}$ \\
\hline Toplam & $\mathbf{4 0 1}$ &
\end{tabular}

Çalışmaya veri toplamak amacıyla sorulan sorulardan biri de katılımcıların marketlerden alışveriş yapma sıklığı olmuştur. Tablo 3'te de görülebileceği gibi tüketicilerin büyük bir bölümünün (\%49,4) haftada en az 23 defa marketlere uğradıkları anlaşılmaktadır. Her gün marketten alışveriş yapanların oranı ise \%22,7 olarak belirlenmiştir. Bu sonuçlar ankete katılan bireylerin araştırma konusu ile ilgili bir fikre görüşe sahip olabileceği ve tutarlı saptamalar yapabileceğini gösterebilir.

Tablo 3. Bireylerin Alışveriş Yapma Sıklıkları

\begin{tabular}{ccc}
\hline Alışveriş Sıklığı & n & \% \\
\hline Her gün & 94 & 22,7 \\
Haftada 2-3 defa & 204 & 49,4 \\
Haftada 1 defa & 60 & 14,7 \\
Ayda 2-3 defa & 25 & 6,1 \\
Ayda 1 defa & 18 & 4,4 \\
\hline Toplam & $\mathbf{4 0 1}$ & $\mathbf{1 0 0}$ \\
\hline
\end{tabular}

Araştırmada katılımcılardan elde edilmek istenen bir diğer önemli bilgi de verilen ürün kategorilerinden hangilerinde çevre dostu ambalaj kullanımına en çok dikkat ettikleridir. Bu bağlamda katılımcılara yedi genel kategori tanımlanmış ve bunlar arasından önem derecesine göre bir sıralama yapmaları beklenmiştir. Çıkan frekans sonuçları ve yüzdelik değerlere bakıldığında; önem sıralamasında ilk sırada gıda ürünlerinde çevre dostu ambalajlı ürün kullanımına dikkat edenlerin çoğunlukta olduğu gözlenmektedir $(\% 51,1)$. Aynı kategoride ikinci derecede çevre dostu ambalajlı ürün kullanımını önemli bulanların oranı ise \%20,4 olarak saptanmıştır. Gıda ürünlerinden sonra önem sıralamasına göre çevre dostu ambalajlı ürün kullanımına dikkat edenlerin ilk sırada yer verdikleri kategori içecek kategorisi (\%18) olurken bunu sırasıyla; bebek bakımı ürünleri $(\% 13,5)$, kişisel bakım ve kozmetik ürünleri $(\% 8,7)$, temizlik ürünleri $(\% 4)$, elektronik ürünleri $(\% 2,2)$ ve zücaciye (\%1) ürünlerinin takip ettiği anlaşılmaktadır. 


\section{Hipotez Testleri}

Çalı̧̧ma kapsamında fiyat, tasarım, algılanan kalite, çevresel tutum, beklenen fayda ve bilgi birikimi değişkenlerinin tüketicilerin çevre dostu ambalajlı ürünlere yönelik tutumları üzerindeki etkisinin ölçmek amacıyla $\mathrm{H}_{1}$ hipotezine "Çoklu Regresyon Analizi" yapılmıştır (Tablo 5). Çoklu Regresyon Analizi, iki değişkenli regresyon analizinin, regresyon denkleminde birden fazla bağımsız değişkenin kullanıldığı bir uzantısıdır. Bağımsız değişkenlerin eklenmesi, regresyona ilave boyut veya eksen katacağı için kavramsallaştırılmasını zorlaştırmaktadır. Ancak, tahminler normalde bir faktör yerine çok sayıda faktöre bağlı olduğu için, bağımsız değişkenlerin sayısının artması regresyon modelini daha gerçekçi hale getirmektedir. Çoklu regresyonun tüm özellikleri ki değişkenli regresyonla benzerlik göstermektedir. Aralarındaki temel fark, çoklu regresyonda birden fazla bağımsız değişkenin kullanılmasıdır. Çoklu regresyon güçlü bir araçtır, çünkü hangi değişkenlerin bağımlı değişkenle ilişkili olduğunu, her bir faktörün bağımlı değişkeni nasıl ve ne kadar etkilediğini göstermektedir (Burns ve Bush, 2015: 384-385). Araştırmanın ana hipotezinde birden fazla bağımsız değişkenin test edilmesi amaçlandığından Çoklu Regresyon analizi kullanılmıştır. H1 hipotezine yapılan analiz sonucunda değişkenlerin, tüketicilerin tutumları üzerindeki etkisi istatistiki açıdan anlamlı bulunmuş, $\mathrm{H} 1$ hipotezi kabul edilmiştir (sign: 0,000). $\mathrm{R}$ değerine göre $(0,814)$ değişkenler arasında pozitif ve kuvvetli bir ilişkinin var olduğu görülürken, determinasyon katsayısına göre $\left(R^{2}=0,662\right)$ fiyat, tasarım, algılanan kalite, çevresel tutum, beklenen fayda ve bilgi birikimi değişkenlerinin tüketicilerin çevre dostu ambalaja yönelik tutumları üzerindeki etkisinin \%66 olduğunu söylemek mümkündür. Beta katsayılarına bakıldığında ise; tüketicilerin tutumlarına etkisinin en yüksek olan değişkenin beklenen fayda $(\beta=0,512)$ olduğu görülürken, bunu sırasıyla, çevresel tutum $(\beta=0,20)$, tasarım $(\beta=0,187)$, algılanan kalite $(\beta=0,079)$, bilgi birikimi $(\beta=0,060)$ değişkenleri takip etmektedir. En az etki eden değişkenin ise fiyat değişkeni $(\beta=0,015)$ olduğu belirlenmiştir.

Doğrusal regresyon analizinin temel varsayımlarından biri, hata terimlerinin sıfır ortalama ve sabit varyansla normal dağılmalıdır (Alpar, 2013). Regresyon modellerinde hataların otokorelasyonuna karşı en yaygın test Durbin-Watson'un sınır testidir (Dufour ve Dagenais, 1985). Durbin-Watson d denklemi ile tanımlanır ve üst ve alt sınırı sırasıyla $\mathrm{d} 1$ ve du olarak tablolandırırlar. Test prosedürü şu şekilde özetlenebilir: $\mathrm{d}<\mathrm{d} 1$ ise, pozitif seri korelasyon olmadığı yönündeki sıfır hipotezini reddedilir; $\mathrm{d}>\mathrm{du}$ ise sıfır hipotezini kabul edilir; $\mathrm{d} 1 \leq \mathrm{d} \leq$ $\mathrm{du}$ ise test sonuç vermez (Habibagahi ve Pratschke, 1972). Otokorelasyonun belirlenmesi için yapılan DurbinWatson testine göre, modelde otokorelasyon olmadığı saptanmıştır (DW=1,91) (Tablo 4).

Tablo 4. H1 Hipotezine ait Genel Değerler

\begin{tabular}{cccccc}
\hline Model & $\mathrm{R}$ & $\mathrm{R} 2$ & Adjusted R2 & Std. Err. & Durbin-Watson \\
\hline 1 &, $814^{\mathrm{a}}$ &, 662 &, 657 &, 36800 & $\mathbf{1 , 9 1 6}$ \\
\hline
\end{tabular}

Çoklu Doğrusal Regresyon Analizi ile ilgili bir başka varsayım, iki açıklayıcı değişken ilişkilendirildiğinde var olan çoklu bağlantı doğrusallık problemidir (Mazzocchi, 2011). Çoklu doğrusallığ tahmin etmenin bir yolu, kestiricilerle ilişkilendirildiğinde tahmini bir regresyon katsayısının varyansının ne kadar arttığını değerlendiren varyans şişme faktörüdür (VIF). Hiçbir faktör ilişkilendirilmediyse, VIF'lerin tümü 1 olacaktır. Varyans şişme faktörü (VIF) 1'e eşitse, regresörler arasında çoklu eşleniklik yoktur, ancak VIF 1'den büyükse, regresörler orta derecede ilişkili olabilir. 5 ve 10 arasındaki bir VIF, sorunlu olabilecek yüksek korelasyonu göstermektedir. VIF ve tolerans değerlerine göre, bağımsız değişkenler arasında çoklu eş doğrusallık probleminin olmadığı görülmektedir (Tablo 5). 
B. Özsaçmac1 - H. Özdemir 12/3 (2020) 2682-2701

Tablo 5. H1 Hipotezine ait Çoklu Regresyon Analizi Sonuçları

\begin{tabular}{llllll}
\hline & & & & \multicolumn{3}{c}{ Çoklu Bağlant İstatistikleri } \\
\cline { 5 - 6 } & Beta & $\mathrm{t}$ & Sig. & Tolerans & VIF \\
\cline { 5 - 6 } (Constant) & &,- 273 &, 785 & & 1,939 \\
\hline Bilgi Birikimi &, 060 & 1,474 &, 141 &, 516 & 1,716 \\
\hline Tasarım &, 187 & 4,843 &, 000 &, 583 & 1,905 \\
\hline Alg. Kalite &, 079 & 1,951 &, 052 &, 525 & 1,990 \\
\hline Çevresel Tutum &, 200 & 4,827 &, 000 &, 502 & 2,254 \\
\hline Beklenen Fayda &, 512 & 11,582 &, 000 &, 444 & 1,433 \\
\hline Fiyat &,- 015 &,- 434 &, 665 &, 698 & \\
\hline
\end{tabular}

Bağımlı Değişken: Tutum

$R=0,814, R^{2}=0,662, F=127,273$, sign $.=0,000$

Fiyat, tasarım, algılanan kalite, çevresel tutum, beklenen fayda ve bilgi birikimi değişkenlerinin tüketicilerin çevre dostu ambalajlı ürünleri satın alma niyetlerine etkisini ölçmek amacıyla $\mathrm{H}_{2}$ hipotezine yapılan Çoklu Regresyon Analizi sonucunda anlamlılık düzeyi 0,05'ten küçük çıktığı için (sign: 0,000) H2 hipotezi kabul edilmiştir (Tablo 6).

Tablo 6. $\mathrm{H}_{2}$ Hipotezi Analizine ait Çoklu Regresyon Analizi Sonuçları

\begin{tabular}{|c|c|c|c|c|c|}
\hline & \multirow{2}{*}{ Beta } & \multirow{2}{*}{$\mathrm{t}$} & \multirow{2}{*}{ Sig. } & \multicolumn{2}{|c|}{ Çoklu Bağlantı İstatistikleri } \\
\hline & & & & Tolerans & VIF \\
\hline (Constant) & & 2,205 & ,028 & & \\
\hline Bilgi Birikimi & ,169 & 3,744 & ,000 &, 516 & 1,939 \\
\hline Tasarım & 233 & 5,481 & ,000 &, 583 & 1,716 \\
\hline Alg. Kalite & 194 & 4,334 & ,000 &, 525 & 1,905 \\
\hline Çevresel Tutum & 051 & 1,111 & ,267 &, 502 & 1,990 \\
\hline Beklenen Fayda & ,307 & 6,286 & ,000 & ,444 & 2,254 \\
\hline Fiyat & ,095, & 2,451 & 015, & 698, & 1,433 \\
\hline
\end{tabular}

a. Bağımlı Değişken: Satın Alma

$R=0,767, R^{2}=0,588, F=92,769$, sign $=0,000$

$\mathrm{R}$ değerine göre $(0,767)$ değişkenler arasında pozitif ve kuvvetli bir ilişkinin var olduğu görülürken, determinasyon katsayısına göre $\left(R^{2}=0,588\right)$ fiyat, tasarım, algılanan kalite, çevresel tutum, beklenen fayda ve bilgi birikimi değişkenlerinin tüketicilerin çevre dostu ambalajlı ürünleri satın alma niyetleri üzerindeki etkisinin \%58,8 olduğunu söylemek mümkündür. Beta katsayılarına bakıldığında ise; tüketicilerin satın alma niyetlerine etkisinin en yüksek olduğu değişkenin beklenen fayda $(\beta=0,307)$ olduğu görülürken bunu sırasıyla; tasarım $(\beta=0,233)$, algılanan kalite $(\beta=0,194)$, bilgi birikimi $(\beta=0,169)$ ve fiyat değişkeni $(\beta=0,095)$ izlemektedir. 
B. Özsaçmac1 - H. Özdemir 12/3 (2020) 2682-2701

Tüketicilerin satın alma niyetine en az etki eden değişkenin ise çevresel tutum $(\beta=0,051)$ olduğu belirlenmiştir. İlk hipotezde olduğu gibi modelde otokorelasyon olmadığı saptanmış ( $\mathrm{DW}=1,96)$ ve VIF-tolerans değerlerine göre, bağımsız değişkenler arasında çoklu eşdoğrusallık probleminin olmadığı görülmektedir (Tablo 6-7).

Tablo 7. $\mathrm{H}_{2}$ Hipotezine ait Genel Değerler

\begin{tabular}{cccccc}
\hline Model & $\mathrm{R}$ & $\mathrm{R} 2$ & Adjusted R2 & Std. Error & Durbin-Watson \\
\hline 1 &, $767^{\mathrm{a}}$ &, 588 &, 582 &, 40782 & $\mathbf{1 , 9 6 0}$ \\
\hline
\end{tabular}

Araştırma kapsamında, çevre dostu ambalajlı ürüne yönelik tutumun tüketicilerin satın alma niyeti üzerindeki etkisi analiz edilmiş, elde edilen analiz sonuçlarına göre anlamlılık düzeyi 0,05 'ten küçük çıtığ 1 için $\mathrm{H}_{3}$ hipotezi kabul edilmiştir. $\mathrm{R}$ değeri $(0,755)$ değişkenler arasında pozitif ve kuvvetli bir ilişkinin var olduğunu işaret ederken, determinasyon katsayısına göre $\left(\mathrm{R}^{2}=0,571\right)$ ise çevre dostu ambalajlı ürüne yönelik tutumun tüketicilerin satın alma niyetine etkisinin \%57 olduğu anlaşılmaktadır.

Tablo 8. H3 Hipotezine ait Genel Değerler

\begin{tabular}{cccccc}
\hline Model & $\mathrm{R}$ & $\mathrm{R} 2$ & Adjusted R2 & Std. Error & Durbin-Watson \\
\hline 1 &, $755^{\mathrm{a}}$ &, 571 &, 569 &, 41375 & $\mathbf{1 , 9 2 0}$ \\
\hline
\end{tabular}

Yapılan çoklu regresyon analizi sonucunda hipoteze ait modelde otokorelasyon olmadığı saptanmış (DW=1,92) veVIF-tolerans değerlerine göre, bağımsız değişkenler arasında çoklu eşdoğrusallık probleminin olmadığı görülmektedir (Tablo 9).

Çalışmada analiz edilen bir diğer hipotez, çevre dostu ambalajlı ürüne yönelik farkındalık durumunun tüketicilerin satın alma niyetleri üzerindeki etkisini incelemektedir. Analiz sonucunda değișkenlerin, tüketicilerin tutumları üzerindeki etkisi istatistiki açıdan anlamlı bulunmuş, $\mathrm{H}_{4}$ hipotezi kabul edilmiştir (sign: $0,000)$. $R$ değeri $(0,473)$ değişkenler arasında göreceli olarak pozitif ve kuvvetli bir ilişkinin var olduğunu işaret ederken, determinasyon katsayısına $\left(R^{2}=0,224\right)$ göre ise çevre dostu ambalajlı ürüne yönelik farkındalık durumunun tüketicilerin satın alma niyetine etkisinin \%22 olduğu anlaşılmaktadır.

Tablo 9. $\mathrm{H}_{1}$ Hipotezine ait Çoklu Regresyon Analizi Sonuçları

\begin{tabular}{|c|c|c|c|c|c|c|}
\hline \multirow[t]{3}{*}{ Model } & & \multirow{2}{*}{$\begin{array}{l}\begin{array}{l}\text { Standardize } \\
\text { Katsayilar }\end{array} \\
\text { Beta }\end{array}$} & \multirow{2}{*}{$\mathrm{t}$} & \multirow{2}{*}{ Sig. } & \multicolumn{2}{|c|}{ Çoklu Bağlantı İstatistikleri } \\
\hline & & & & & Tolerans & VIF \\
\hline & (Constant) & & 13,518 & ,000 & & \\
\hline 1 & Tutum & ,755 & 22,906 & ,000 & 1,000 & 1,000 \\
\hline
\end{tabular}

Bağımlı Değişken: Satın Alma $R=0,755, R^{2}=0,571, F=524,678$, sign. $=0,000$

Tutumun cinsiyetlere göre farklılaşıp farklılaşmadığını görmek amacıyla $\mathrm{H}_{5}$ hipotezine T-testi uygulanmıştır. Levene Testi sonuçlarına göre (sign: 0,420) varyansların eşit olduğu görülmektedir. Buna göre, tüketicilerin tutumlarının cinsiyetlere göre farkı istatistiki açıdan anlamlı bulunmamıştır (sign: 0,088). Analiz sonuçlarına göre $\mathrm{H}_{5}$ hipotezi reddedilmiştir.

Tutumun gelir düzeylerine göre anlamlı bir farklılık gösterip göstermediğini test etmek amacıyla $\mathrm{H}_{6}$ hipotezine ANOVA analizi yapılmıştır. Anlamlılık düzeyine göre (sign: 0,521) tüketicilerin tutumlarının gelir düzeylerine göre farklılaşmadığı sonucuna varılmıştır. Bu noktadan hareketle $\mathrm{H}_{6}$ hipotezi reddedilmiştir. 
Tutumun yaş gruplarına göre anlamlı bir farklılık gösterip göstermediğini test etmek amacıyla $\mathrm{H}_{7}$ hipotezine ANOVA analizi yapılmıştır. Gruplar arasındaki anlamlılık düzeyine göre (sign: 0,834) tüketicilerin tutumlarında gelir düzeylerine göre herhangi bir farklılaşma olmadığı anlaşılmıştır. Bu analiz sonucuna göre $\mathrm{H} 7$ hipotezi reddedilmiştir.

Tutumun eğitim düzeyine göre anlamlı bir farklılık gösterip göstermediğini test etmek amacıyla $\mathrm{H}_{8}$ hipotezine ANOVA analizi yapılmıştır. Gruplar arasındaki anlamlılık düzeyine göre (sign: 0,740) tüketicilerin tutumlarında eğitim düzeylerine göre herhangi bir farklılaşma olmadığı anlaşılmıştır. Bu bağlamda yapılan test sonuçları $\mathrm{H} 8$ hipotezinin desteklenmediğine işaret etmektedir.

Yapılan analizler sonucunda, çevre dostu ambalajlı ürüne yönelik tüketici tutumlarının demografik faktörlere göre farklılaşmadığı görülmüş, farklı demografik yapıdaki tüketicilerin çevre dostu ambalajlara karşı benzer tutum içinde oldukları belirlenmiştir.

\section{Sonuç ve Tartışma}

Çevre dostu ambalaj konusu yaklaşık on yılı aşkın bir süreçte ülkemiz gündemindeki yerini arttırmaktadır. Özellikle sürdürülebilirlik yaklaşımının benimsenmesiyle birlikte, çeşitli sektörlerdeki söz sahibi işletmelerin bütün süreçlerini yeniden yapılandırıp çevreci hale dönüştürdükleri gözlenmektedir. Bu dönüşüm içerisindeki önemli aktörlerden biri de işletmelerin ürünlerini sarmalayan ve onlara bir kimlik kazandıran ambalajlardır. Uygulamada bazı işletmeler ambalajlarını hafifletme ya da azaltma yoluna giderken, diğer bir kısmı ise geri dönüştürülebilir ya da doğada çözünebilen/kaybolan malzemeleri tercih etmektedirler. Burada işletmelerin birincil hedefi, çevresel tutum ve farkındalıkları her geçen gün artan tüketicilerin beklentilerine cevap verebilmek iken diğer taraftan çevrenin korunmasına katkı sağlanması da ön planda tutulmaktadır.

$\mathrm{Bu}$ çalı̧̧ma temel olarak çevre dostu ambalajlı market ürünlerine ait fiyat, tasarım, algılanan kalite, çevresel tutum, beklenen fayda ve bilgi birikimi değişkenlerinin tüketicilerin tutumlarına, farkındalıklarına ve satın alma niyetlerine etkisini ortaya koymayı amaçlamaktadır. Çalışmada belirtilen amaca ek olarak ve çevre dostu ambalajlama faaliyetlerinden de yola çıkılarak; tüketicilerin sahip olduğu çevresel tutum ve farkındalık bilincinin ve anlayışının artırılması da hedeflenmektedir.

Literatürde yer alan benzer çalışmalara (Prakash ve Pathak, 2016; Pillai ve Junare, 2016; Royne vd., 2011; Newell ve Green, 1997) bakıldığında geliştirilen hipotezlerin sonuçları açısından benzerlikler gösterdiği gözlenirken, yaş, cinsiyet, gelir seviyesi ve eğitim düzeyi gibi demografik sonuçların farklılaştığ1 anlaşılmaktadır. Royne vd., (2011), analiz sonuçlarına göre genç, iyi eğitimli ve sabit gelire sahip bireylerin çevre dostu özellikli ürünler konusunda daha duyarlı olduklarını ifade etmişlerdir. Buna karşın Chen ve Chiu (2016) ve Khare (2015), demografik değişkenlerin tüketicilerin çevre dostu satın alma niyetlerine etkisi olmadığını belirtmişlerdir.

Araştırmanın kavramsal çerçevesinin uyumlaştırıldı ̆̆ Prakash ve Patak (2017)'ın çalışmasında benzer olarak, çevre dostu ambalajlı ürünlere yönelik tutumun çevresel tutumdan etkilendiği ve bunun da satın alma niyetini etkilediği tespit edilmiştir. Bu çalışmada elde edilen bir diğer bulgu da çevre dostu ambalajl ürünlere yönelik farkındalığın satın alma niyetini etkilediği yönündedir. Çalışmadaki önemli sonuçlardan biri de tüketicilerin karakteristik sosyo demografik faktörlerinin çevre dostu ambalajlı ürünlere yönelik tutuma göre anlamlı bir farklılık oluşturmadıklarıdır. Buna karşın literatürdeki benzer çalışmalar (Donk ve Fuller, 2010; Tait vd., 2016) tüketicilerin eğitim ve gelir seviyeleri arttıkça çevre dostu ambalajlı ürünlere yönelimin arttığını ifade etmektedir.

van Birgelen vd., (2009) ve Tseng ve Tsai (2011) yaptıkları çalışmada farkındalık ve çevresel tutum konuları ele alınmış, bunların çevre dostu satın alma niyeti ile ilişkilendirildiğini ortaya koymuştur. Bu çalışmada da benzer şekilde tüketicilerin çevre dostu ambalajlı ürünlere yönelik farkındalık düzeyleri ve tutumun istatistiki olarak anlamlı bir ilişkiye sahip olduğu anlaşılmıştır. Bu doğrultuda pazarlama yöneticilerinin çevre dostu bilinci arttırmaya yönelik çabalarının, orta-uzun vadede tüketicilerin çevre dostu ürün arayışlarını arttırabileceğini söylemek yanlış olmayacaktır. Bir anlamda pazarlama yöneticileri ürün/marka ambalajları üzerindeki çevre dostu uygulamaların tüketicilerden daha fazla reaksiyon alabileceği ifade edilebilir.

Bu çalışma kapsamında incelenen değişkenlerden fiyat değişkeni, tüketicilerin çevre dostu ambalajlı ürünlere yönelik tutumları sıralamasında en alt sırada yer alırken, beklenen fayda değişkeni ise en üst sırada yer 
almıştır. Ritter vd., (2015) ve Chekima vd., (2015), çalışmalarında fiyatın çevre dostu ürün tercihinde birincil unsur olmadığını ifade etmiş ve fiyat değişkeni konusunda bu çalışma ile benzer sonuçlara ulaşmışlardır. Buna karşın Khan ve Mohsin (2017)'in çalışmasında tüketicilerin çevre dostu ürün seçiminde dikkatini çeken ilk unsurun fiyat olduğu ifade etmiş, Dekhili ve Achabou (2012) ve Smith ve Brower (2012) tüketicilerin çevrenin korunması söz konusu olduğunda çevre dostu ürünler için fiyatlar hassasiyeti göstermediklerini belirtmişlerdir.

Ülkemizde önemi giderek artan çevre dostu uygulamaların; bu konuda yapılacak çalısmaların sayısının da artması ile çevre dostu ürünlere ve onların özelliklerine ilişkin bilinç ve tutumu olumlu yönde etkileyeceği düşünülmektedir. Sektörde yer alan yöneticiler mevcut çalışmadan elde edilen bulgular doğrultusunda birtakım pratik uygulamalar geliştirebilirler. Örneğin; tasarım anlamında tüketicilerin ilgisini çekebilecek ve çevre dostu özellikleri ön plana çıkaracak (yarışma, indirim ve kupon/armağan dağıtımı gibi) satış tutundurma seçenekleri sunmak, çevre dostu ambalajlama konusunda yeni trendleri takip eden ve bu doğrultuda üretim yapan ambalaj üreticileriyle anlaşmak, yapılan çevre dostu uygulamaların çevreye katkılarını sergileyen çarpıcı reklam filmleriyle tüketici tutumunu ve talebini çevre dostu ambalajlı ürünlere kaydırmaya çalışmak ve ürünlerin kalitesini etkilemeyecek ölçüde, tasarım aşamasında, daha az malzeme ve kaynak kullanılmasıyla çevre dostu üretim süreçlerinin benimsenmesi bir seçenek olarak sunulabilir.

Farklı sektör, ürün grupları ve örneklem büyüklükleriyle yapılacak çalışmalar, daha kesin ve tutarlı sonuçlar elde edilmesine olanak sağlayabilecektir. Bu çalışma temel olarak niyet ölçümü üzerine odaklanmıştır, gelecekte yapılacak çalışmaların davranış ölçümüne odaklanması daha etkili bulgulara ulaşılmasına katkı verebilecektir.

\section{Kaynakça}

Agyeman, C. M. (2014). Consumer' buying behaviour towards green product: An exploratory study, International Journal of Management Research and Business Strategy, 3(1), 194.

Alavi, M. and Leidner, D. (2001). Review: Knowledge Management and Knowledge Management Systems. Conceptual Foundations and Research Issues, MIS Quarterly, 25(1), 107-136.

Alpar, R. (2013). Çok değişkenli istatistiksel yöntemler, Ankara, Detay Yayıncılık (4. Baskı).

Angeles, R. (2014). Using the technology-organization-environment framework for analyzing nike's "considered index" green initiative, a decision support system-driven system, Journal of Management and Sustainability, 4(1), 96-109.

Ajzen, I. and Fishbein, M. (1980). Understanding attitudes and predicting social behaviour, Englewood Cliffs, N.J: Prentice-Hall.

Banerjee, T. (2015). Impact of energy efficiency on consumer purchase decision: a study on household products in India, ASBM Journal of Management. 8, 68-77.

Barbara, S. (2012). Puma Embraces Sustainable Packaging with Their Clever Little Bag Concept. Malaysia: Be Green Packaging LCC. https://begreenpackaging.wordpress.com/2012/09/ 28/puma-embracessustainable-packagingwith - their-clever-little-bag-concept/

Batı, U. (2017). Sineztezik marka yönetme: satın almanın doğasına dair ilham verici şeyler. https://pazarlamasyon.com/sineztezik-marka-yonetme-satin-almanin-dogasina-dair-ilham-vericiseyler (Erişim Tarihi: 24.11.2017).

Ben-Akiva, M., Bradley, M., Morikawa, T., Benjamin, J., Novak, T. P., Thomas, P., Oppewal, H. and Rao, V. (1994). Combining revealed and stated preferences data, Marketing Letters, 5 (4), 335-50.

Boks, C. and Stevels, A. (2007). Essential perspectives for design for environment. Experiences from the electronics industry, International Journal of Production Research, 45(18-19), 4021-4039.

Breidert, C., Hahsler, M. and Reutterer, T. (2006). A reveiw of methods for measuring willingness-to-pay, Innovative Marketing, 2 (4), 8-32.

Brockhaus, S., Petersen, M. and Kersten,W. (2016). A crossroads for bioplastics: exploring product developers' challenges to move beyond petroleum-based plastics, Journal of Cleaner Production, 127, 84-95. 


\section{B. Özsaçmacı - H. Özdemir 12/3 (2020) 2682-2701}

Burns, A. C. and Bush, R. F. (2015). Marketing reseach-Pazarlama araştırması (7.Baskı). Ankara: Nobel Akademik Yayıncilık.

Büsser, S., Steiner, R. and Jungbluth, N. (2008). LCA of food products/packed goods: coffee, butter, spinach. Brussels: ESU Services Ltd. for Flexible Packaging Europe, Uster.

Chang, N.J. and Fong, C.M. (2010). Green product quality, green corporate image, green customer satisfaction, and green customer loyalty, African Journal of Business Management, 4(13), 2836-2844.

Cheah, I. and Phau, I. (2011). Attitudes towards environmentally friendly products: The influence of ecoliteracy, interpersonal influence and value orientation, Marketing Intelligence and Planning, 29(5), 452-472.

Chen, Y. (2010). Towards green loyalty: driving from green perceived value, green satisfaction, and green trust, Sustainable Development, 21(5), 294-308.

Chen, M. and Chiu, C. (2016). Go green: how to influence the perceived effectiveness of a green product? International Journal of Advertising, 35(4), 622-641.

Chekima, B., Syed Khalid Wafa, S., Igau, O., Chekima, S. and Sondoh, S. (2015). Examining green consumerism motivational drivers: does premium price and demographics matter to green purchasing? Journal of Cleaner Production, 112(4), 3436-3450.

Creyer, H. E. (1997). The influence of firm behavior on purchase intention: do consumers really care about business ethics? Journal of Consumer Marketing, 14(6), 421-432.

Daşdemir, İ. (2016). Bilimsel araştırma yöntemleri, Ankara: Nobel Akademik Yayıncılık.

Dekhili, S. and Achabou, M. (2012). Price fairness in the case of green products: enterprises' policies and consumers' perceptions, Business Strategy and the Environment, 22(8), 547-560.

DiPietro, R.B. and Gregory, S. (2012). Customer perceptions regarding green restaurant practices: A comparison between fast food and upscale casual restaurants, FIU Hospitality Review, 30(1), 1-22.

DiPietro, R., Gregory, S. and Jackson, A. (2013). Going green in quick-service restaurants: Customer perceptions and intentions, International Journal of Hospitality and Tourism Administration, 14(2), 139156.

Dong, F. and Fuller, F. (2010). Dietary structural change in China's cities: empirical fact or urban legend? Canadian Journal of Agricultural Economics, 58 (1), 73-91.

Drozdenko, R., Jensen M. and Coelho D. (2011). Pricing of green products: Premiums paid, consumer characteristics and incentives, International Journal of Business, Marketing and Decision Sciences, 4(1), 106116.

Dufour, J. M. and Dagenais, M. G. (1985). Durbin-Watson tests for serial correlation in regressions with missing observations, Journal of Econometrics, 27(3), 371-381.

Fitzpatrick, L., Verghese, K. and Lewis, H., (2012). Developing the strategy. In: Verghese, K., Lewis, H., Fitzpatrick, L. (Eds.), Packaging for Sustainability. Springer, Heidelberg, 1-39.

Giannelloni, J.L. (1998). Environment-related behaviors and their aetiology: A review of marketing research, Recherche et Applications en Marketing, 13(2), 49-72.

Habibagahi, H. and Pratschke, J. (1972). A Comparison of the Power of the Von Neumann Ratio, DurbinWatson and Geary Tests, The Review of Economics and Statistics, 54(2), 179-185.

Han, H., Hsu, L.T.J. and Lee, J.S., (2009). Empirical investigation of the roles of attitudes toward green behaviors, overall image, gender, and age in hotel customers' ecofriendly decision-making process, International Journal of Hospitality Management, 28 (4), 519-528.

Hasan, J.Hartoyo, Sumarwan, U. and Suharjo, B. (2012). Factors analysis in desire to buy environmental friendly products: case study for air condition products, International Business Research, 5, 181-189. 


\section{B. Özsaçmacı - H. Özdemir 12/3 (2020) 2682-2701}

Herbes, C., Beuthner, C. and Ramme, I. (2018). Consumer attitudes towards biobased packaging: A crosscultural comparative study, Journal of Cleaner Production, 194, 203-218.

Hidalgo-Baz, M., Martos-Partal, M. and Gonzalez-Benito, O. (2017). Is advertising helpful for organic businesses? Differential effects of packaging claims, Inernational Journal of Advertising, 36, 542-561.

Holdway, R., Walker, D. and Hilton, M. (2002). Eco-design and successful packaging, Design Management Journal, 13(4), 5.

Jerzyk, E. (2016). Design and communication of ecological content on sustainable packaging in young consumers' opinions, Journal Food Products Marketing, 22(6), 707-716.

Johnson, M. D. and Ettlie, J. E. (2001). Technology, customization, and reliability, Journal of Quality Management, 6(2), 193-210.

Kabadayı, E., Dursun, İ., Alan, A. and Tuğer, A. (2015). Green purchase intention of young Turkish consumers: Effects of consumer's guilt, self-monitoring and perceived consumer effectiveness, Procedia-Social and Behavioral Sciences, 207, 165-174.

Karatu, V. M. (2015). The mediating role of environmental consciousness. Predictors of green purchase intention in Nigeria, American Journal of Economics, 5(2), 291-302.

Kauppinen-Raisanen, H. and Luomala, H.T. (2010). Exploring consumers' product specific colour meanings, Qualitative Market Research, 13(3), 287-308.

Khan, S. and Mohsin, M. (2017). The power of emotional value: Exploring the effects of values on green product consumer choice behavior, Journal of Cleaner Production, 150, 65-74.

Khare, A. (2015). Antecedents to green buying behaviour: a study on consumers in an emerging economy, Marketing Intelligence and Planning, 33(3), 309-329.

Kim, Y.J., Njite, D. and Hancer, M. (2013). Anticipated emotion in consumers' intentions to select eco-friendly restaurants: augmenting the theory of planned behavior, International Journal of Hospitality Management, 34 (2013), 255-262.

Klaiman, K., Ortega, D.L. and Garnache, C. (2016). Consumer preferences and demand for packaging material and recyclability, Resources, Conservation and Recycling, 115, 1-8.

Kniazeva, M. and Belk, R.W. (2007). Packaging as vehicle for mythologizing the brand, Consumption Markets and Culture, 10(1), 51-69.

Koenig-Lewis, N., Palmer, A., Dermody, J. and Urbye, A. (2014), Consumers' evaluations of ecological packaging - rational and emotional approaches, Journal of Environmental Psychology, 37, 94-105.

Leonidou, C.N., Katsikeas, C.S. and Morgan, N.A. (2013). Greening the marketing mix: do firms do it and does it pay off? Journal of the Academy of Marketing Science, 41 (2), 151-170.

Lewis, H., Fitzpatrick, L., Verghese, K., Sonneveld, K. and Jordon, R. (2007). Sustainable packaging redefined. Draft. Melbourne: Sustainable Packaging Alliance.

Limbu, Y.B., Wolf, M. and Lunsford, D. (2012). Perceived ethics of online retailers and consumer behavioral intentions: the mediating roles of trust and attitude, Journal of Research in Interactive Marketing, 6 (2), 133-154.

Magnier, L. and Crié, D. (2015). Communicating packaging eco-friendliness: An exploration of consumers' perceptions of eco-designed packaging, International Journal of Retail and Distribution Management, 43(45), 350-366.

Magnier, L. and Schoormans, J. (2015). Consumer reactions to sustainable packaging: the interplay of visual appearance, verbal claim and environmental concern, Journal of Environmental Psychology, 44, 53-62.

Magnier, L., Schoormans, J. and Mugge, R. (2016). Judging a product by its cover: packaging sustainability and perceptions of quality in food products, Food Quality and Preference. 53, 132-142. 
B. Özsaçmac1 - H. Özdemir 12/3 (2020) 2682-2701

Maichum, K., Parichatnon, S. and Peng, K. (2017). Application of the extended theory of planned behavior model to investigate purchase intention of green products among Thai consumers, Sustainability, 8(10), 1077.

Mainieri, T., Barnett, E. G., Valdero, T. R., Unipan, J. B. and Oskamp, S. (1997). Green buying: the influence of environmental concern on consumer behavior, The Journal of Social Psychology, 137(2), 189-204.

Martinho, G., Pires, A., Portela, G. and Fonseca, M. (2015). Factors affecting consumers' choices concerning sustainable packaging during product purchase and recycling, Resources, Conservation and Recycling, $103,58-68$.

Mazzocchi, M. (2011). Statistics for Marketing and Consumer Research. SAGE Publications Ltd.

Monnot, E., Parguel, B. and Reniou, F. (2015). Consumer responses to elimination of overpackaging on private label products, International Journal of Retail and Distribution Management, 43(4-5), 329-349.

Morel, M. and Kwakye, F. (2012). Green marketing: Consumers' attitudes towards ecofriendly products and purchase intention in the fast moving consumer goods (FMCG) sector. Master's Thesis, Umeå University School of Business.

Nakip, M. ve Yaraş, E. (2017). Pazarlama Araştırma Teknikleri. Ankara: Seçkin Yayıncılık.

Newell, S. and Green, C. (1997). Racial differences in consumer environmental concern, Journal of Consumer Affairs, 31(1), 53-69.

Noor, M.N., Masuod, S., Said, A.A., Kamaruzaman, I.F. and Mustafa, M.A. (2016). Understanding consumers and green product purchase decision in malaysia: a structural equation modeling- partial least square (sem-pls) approach, Asian Social Science, 12(9), 51-64.

Ottman, J., Stafford, E. and Hartman, C. (2006). Avoiding green marketing myopia: ways to improve consumer appeal for environmentally preferable products, Environment, 48, 22-36.

Ozsacmaci, B. (2018). Yeşil pazarlama faaliyetlerinin yeşil marka farkındalığı ve tüketici satın alma niyeti üzerindeki aracllı etkisi, Business and Economics Research Journal, 9(4), 945-960.

Perrault, W., Cannon, J. and Mccarthy, E. (2013). Pazarlamanın temelleri (Çeviri Editörü: A.G. Önce). Nobel Yayınevi: Ankara.

Piqueras-Fizman, B. and Spence, C. (2015). Sensory expectations based on product-extrinsic food cues: an interdisciplinary review of the empirical evidence and theoretical accounts, Food Quality and Preference, 40, 165-179.

Pillai, P. and Junare, D. (2016). A study on consumers' perception towards eco-friendly products in Ahmedabad, International Journal of Research in IT and Management, 6(7), 14-25.

Prakash, G. and Pathak, P. (2017). Intention to buy eco-friendly packaged products among young consumers of India: a study on developing nation, Journal of Cleaner Production, 141(1), 385-393.

Ritter, Á. Borchardt, M., Vaccaro, G., Pereira, G. and Almeida, F. (2015). Motivations for promoting the consumption of green products in an emerging country: exploring attitudes of Brazilian consumers, Journal of Cleaner Production, 106, 507-520.

Rokka, J. and Uusitalo, L. (2008). Preference for green packaging in consumer product choices-Do consumers care? International Journal of Consumer Studies, 32 (5), 516-525.

Royne, M., Levy, M. and Martinez, J. (2011). The public health implications of consumers' environmental concern and their willingness to pay for an eco-friendly product, Journal of Consumer Affairs, 45(2), 329343.

Scott, L. and Vigar-Ellis, D. (2014). Consumer understanding, perceptions and behaviours with regard to environmentally friendly packaging in a developing nation, International Journal of Consumer Studies, $38,642-649$. 
B. Özsaçmacı - H. Özdemir 12/3 (2020) 2682-2701

Shahira, A., Jamaliah, M. Y., Mohd, Y., Lennora, P. and Mohd, Z. (2016). Factors influencing perceived quality and repurchase intention towards green products, Procedia Economics and Finance, 37, 391-396.

Sheth, J.N. (2011). Impact of emerging markets on marketing: rethinking existing perspectives and practices, Journal of Marketing, 75 (4), 166-182.

Skylife Dergi. (2018). Mercek: Yeşil bir dünya için sıfır atık. Aralık, İstanbul, 64-67.

Smith, K. and Brower, T. (2012). Longitudinal study of green marketing strategies that influence Millennials, Journal of Strategic Marketing, 20(6), 535-551.

Stolz, J., Molina, H., Ramírez, J. and Mohr, N. (2013). Consumers' perception of the environmental performance in retail stores: an analysis of the German and the Spanish consumer, International Journal of Consumer Studies, 37, 394-399.

Tait, P., Saunders, C., Guenther, M. and Rutherford, P. (2016). Emerging versus developed economy consumer willingness to pay for environmentally sustainable food production: a choice experiment approach comparing Indian, Chinese and United Kingdom lamb consumers, Journal of Cleaner Production, 124, 65-72.

Tamani, N., Mosse, P., Croitoru, M., Buche, P., Guillard, V., Guillaume, C. and Gontard, N. (2015). An argumentation system for eco-efficient packaging material selection, Computers and Electronics in Agriculture, 113, 174-192.

Thogersen, J. (2011). Green shopping: for selfish reasons or the common good? American Behavior Scientist, 55(8), 1052-1076.

Tseng, C. J. and Tsai, S. C. (2011). Effect of consumer environmental attitude on green consumption decision making, Pakistan Journal of Statistics, 27(5), 699-708.

Tsiotsou, R. (2006). The role of perceived product quality and overall satisfaction on purchase intentions, International Journal of Consumer Studies, 30(2), 207-217.

Türkiye Çevre ve Şehircilik Bakanlığı (2016), Türkiye Çevre Durum Raporu. https://ced.csb.gov.tr/turkiyecevre-durum-raporu-i-82673 (Erişim Tarihi, 08.07.2019).

Underwood, R.L. and Ozanne, J.L. (1998). Is your package an effective communicator? A normative framework for increasing the communicative competence of packaging, Journal of Marketing Communications, 4(4), 207-220.

Üçhisarlı, C. (2019). Yenilebilir ve doğal plastik ambalaj: scoby, https://pazarlamasyon.com/yenilebilir-vedogal-plastik-ambalaj-scoby (Erişim Tarihi, 02.07.2019).

van Birgelen, M., Semeijn, J. and Keicher, M. (2009). Packaging and proenvironmental consumption behavior: investigating purchase and disposal decisions for beverages, Environmental Behavior, 41, 125-146.

Wan, M., Chen, J. and Toppinen, A. (2015). Consumers' environmental perceptions of children's furniture in china, Forest Products Journal, 65(7-8), 395-405.

Wang, H. and Wang, L. (2017). Developing a bio-based packaging film from soya byproducts incorporated with valonea tannin, Journal of Cleaner Production, 143, 624-633.

Wee, C.S., Ariff, M.S.B.M., Zakuan, N., Tajudin, M.N.M., Ismail, K. and Ishak, N. (2014). Consumers perception, purchase intention and actual purchase behavior of organic food products, Review of Integrative Business and Economics Research, 3(2), 378-391.

Wertenbroch, K. and Skiera, B. (2002). Measuring consumers' willingness to pay at the point of purchase, Journal of Marketing Research, 39(2), 228-241.

Wilke, T., Müller, S., Neumann, K. and Loder, T. (2011). Does package design matter for patients? Pharmaceutical Medicine, 25(5), 307-317.

Yaacob, M. R. and Zakaria, A. (2011). Customer's awareness, perception and future prospects of green products in Pahang, Malaysia, The Journal of Commerce, 3 (2), 1-10. 